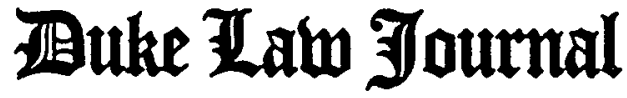

\section{CODIFICATION, REFORM, AND REVISION: THE CHALLENGE OF A MODERN FEDERAL CRIMINAL CODE}

\author{
JoHN L. MCCLELLAN*
}

The four chief factors influencing the quality of American justice were identified by Dean Roscoe Pound as personnel, administration, procedure, and the substantive law.' ${ }^{1}$ It is certain that better judges, prosecutors, and enforcement officers, better organization of courts, better administrative methods, and more adequate administrative personnel must come first in any effective program for the improvement of our nation's system of criminal justice. At the same time, the men who staff that system will be guided by an authoritatively prescribed criminal procedure, and they will be giving effect to an authoritatively prescribed criminal law. An archaic code of procedure and patchwork criminal laws will, of course, give better results if well administered than the most modern procedure or well reasoned, up-to-date substantive criminal law that is ill administered.

* United States Senator from Arkansas. The assistance of G. Robert Blakey, of the Staff of the Senate Subcommittee on Criminal Laws and Procedures, and David P. Bancroft, of the Department of Justice, presently with the United States Attorney's Office in San Francisco, in the collection of these materials, drawn in part from an address on the Senate floor, is gratefully acknowledged. For the address and the text of the proposed Code, see 117 CoNG. REC.S. 2955-3006 (danly ed. March 11, 1971).

1. Pound, Toward a Better Criminal Law, 60 A. B.A. REP. 322 (1935). It is evident, too, as Pound concluded, that these factors must be ranked in this same order of relative importance. Id.

THE FOLLOWING HEREINAFTER CITATIONS ARE USED IN THIS ARTICLE:

H.R. ReP. No. 304, 80th Cong., lst Sess. (1947) [hereinafter cited as H.R. Rep. No. 304];

3 R. Pound, Jurisprudence (1959) [hereinafter cited as 3 R. Pound];

final Report of the National Commission on Reform of Federal Criminal laws (1971) [hereinafter cited as FINAL REPORT], [sections of the proposed Code hereinafter cited as Proposed CODE]. 
Nevertheless, the conclusion seems unavoidable that the satisfactory administration of criminal justice must ultimately rest, as Dean Pound noted, upon a satisfactory criminal code. ${ }^{2}$ This means, in short, that concern with the improvement of our system of criminal justice must embrace reform of not only personnel, administration, and procedure, but also of the substantive law itself.

It was with these conclusions in mind that the National Commission on Reform of Federal Criminal Laws was established in $1966 .^{3}$ It was charged with the important duty of making a complete review of the statutory and case law of the United States "for the purpose of formulating and recommending to the Congress legislation which would improve the federal system of criminal justice . . . [and to recommend] the repeal of unnecessary or undesirable statutes and such changes in the penalty structure as . . . will better serve the ends of justice." After nearly three years of deliberation by the Commission, its advisory committee, consultants, and staff, its Final Report has now been published and forwarded to the President and the Congress. ${ }^{5}$ Although it constitutes the most comprehensive call for reconsideration of federal penal policy ever issued, it must be emphasized that the Commission's recommendations were submitted solely as a "work basis" upon which the Congress itself, reflecting the judgment of the nation, might undertake the necessary reform of the substantive criminal law.

As Congress and the nation now embark upon the task of evaluating the recommendations and proposals of the Commission, ${ }^{6}$ it

2. Pound, 60 A.B.A. ReP. 322 , supra note 1.

3. Act of Nov. 8, 1966, Pub. L. No. $89-801, \S 8,80$ Stat. 1516, as amended, Act of July 8 . 1969, Pub. L. No. 91-39, 83 Stat. 44, codified at 18 U.S.C. (Supp. V, 1970) (prior to § 1).

4. Act of Nov. 8, 1966, Pub. L. No. 89-801, § 3,80 Stat. 1516.

5. A copy of the FINAL RePORT may be obtained for $\$ 1.75$ from the Superintendent of Documents, U.S. Government Printing Office, Washington, D.C. 20402. Volumes I and II of the Working Papers, published in August, 1970, and the StUdY Draft, published in June, 1970 , may be similarly purchased for $\$ 8.25$. A third volume of WORKING PAPERS, prepared under the auspices of the Senate Subcommittee on Criminal Laws and Procedures, sliould be available by the time this article appears. The FINAL REPORT is also reprinted with a transcript of the first day of hearings of the Senate Subcommittce on Criminal Laws and Procedures concerning the recommendations of the Commission, which were held February 10, 1971. Hearings Before the Subcomm. on Criminal Laws and Procedures of the Senate Conm. on the Judiciary. 92nd Cong., 1st Sess., pt. 1 (1971) (Reform of the Federal Criminal Law). Other hearings were held in May and June, and more are expected in the coming months.

6. The work that the Congress is undertaking on the national level parallels work cither recently completed or now underway on the state level. The status of the codification movement is reflected in an appendix to this article. See pp. 714-16 infra. Much of it stems from the work 
is appropriate, as a preface to that effort, to examine the history of other attempts at codification, reform, and revision, as well as the growth of the federal criminal law. For, as Maitland long ago observed, "[t]o-day we study the day before yestcrday, in order that yesterday may not paralise to-day, and to-day may not paralise tomorrow."7

\section{THE History OF CODIFICATION}

The subject of codification is intimately connected with the idea of a written law. It is part of the seemingly universal demand for a complete, intelligible, and authoritative statement of the precepts governing the relation of the individual's personal conduct and the state and the demand that, in a civilized community, every man should be assured of knowing what he may and may not do. Few did not call Caligula tyrant when he published his deerees on the columns of Rome too high to be read, in order that he might have more subjects to punish. The idea of a written law accessible to all is thus related to the idea behind our Bill of Rights. It is a part of the quest of a government of laws and not of men, and its history reaches into antiquity. ${ }^{8}$

\section{The Roman Law Background}

Roman law itself had a tradition of written law. Down to the codification of Justinian, the Twelve Tables (450 B.C.) constituted the theoretical foundation of the ius civile. Indeed, Justinian was not the first to envision a code. We are told that Julius Ceasar had among other plans that of making a digest of the law, reducing the ius civile to method, and bringing together the finest and best of the essential works on the law. ${ }^{9}$ But it was not until 429 that Theodosius 11 appointed a commission to compile the imperial legislation after

of the American Law Institute on its Model Penal Code. See generally Wechsler, Codification of Criminal Law in the United States: The Model Penal Code, 68 Colum. L. Rev. 1425 (1968). The overall problem of codification on the state level is considered in Hearings, supra note 5, pt. 2. Empirical data on its impact in Wisconsin (1956), Illinois (1962), and New York (1967) is contained in Hearings, supra note 5, pt. 2. See also Symposium: Recodification of the Criminal Laws, 4 J. LAW ReFORM 425-85 (1971).

7. 3 The Coluected Papers of Fredric William Maitland 439 (H. Fisher ed. 1911).

8. For a complete treatment of the history of codification, see 3 R. Pound 673-738, upon which I have heavily drawn.

9. See D. Dudley, The Civilization of Rome 101 (1962). On the background of the Twelve Tables as a victory for the rule of law of the plebians against the patricians during the Republic, see id. at 34 . 
Constantine. Although this project failed, a subsequent commission completed a work known as the Theodosius Code, which took effect in 439. It was not, however, what we know as a modern code, but was rather little more than a compilation of the law then in effect. ${ }^{10}$

The real work of codification in the Roman law did not begin until 528. Substantially one hundred years after Theodosius' first start, the emperor Justinian, at the insistence of his minister Tribonian, set out to codify the whole of the body of Roman law. A commission of ten, composed of judges, lawyers, and one law professor was appointed to prepare a complete revision of imperial legislation. Its product is known as the "Code," and it was completed in a year. Next, Justinian appointed another commission of sixteen, this time composed of judges, lawyers, and four law professors, to compile and systematize the text book learning of the Roman law-contained in the treatises of the great jurisconsuls and their commentaries. This was completed, rather hastily, in three years, and its product was known as the "Digest"-given legal authority in 533. Finally, an instruetional text was prepared for students by a commission of three, Tribonian and two law professors. Known as the "Institutes," it, too, was given legal authority. Together with the subsequent legislation of Justinian, compiled into what we call the "Novels," these various parts are what we now speak of as Justinian's codification-the great Corpus Juris Civilis. Like the Theodosian Code, it was not what we would call a code today, but it was an enormous achievement. It put in systematic form the results of a thousand years of development of Roman law, and it has inspired other legal systems to this day."

\section{The First Beginning: The Carolina}

In the modern world, the penal code of the German Emperor Charles V-the Constitutio Criminalis Carolina-which was promulgated in 1552 , is the first important legislation that might be properly called a code. It was commonly known as the Carolina, even though the Emperor himself had little to do with its development and enactment. ${ }^{12} \mathrm{~A}$ product of the revived interest in Roman law of the Italian jurists of the sixteenth century, the Carolina was primarily

\footnotetext{
10. See 3 R. Pound 681-87.

11. Gibbon aptly observed: "The vain titles of the victories of Justinian are crumbled into dust; but the name of the legislator is inseribed on a fair and everlasting monument." $2 \mathrm{E}$. Gibbon, The Decline and Fall of the Roman Empire 322 (1932).
}

12. 3 R. POUND 687. 
procedural in character. Yet it is chiefly renowned for introducing into continental legislation aspects of the general doctrines of the criminal law in connection with its treatment of defenses to crimes and its seminal examination of sentencing policy. Nevertheless, at the time of its consideration it was widely opposed, ${ }^{13}$ and its acceptance was made possible only by the famous "Savings Clause," which provided: "In gracious consideration of the electors and the princes and the States [the Emperor did not] desire . . . to detract from their ancient and well established legal and customary usages." 14

On the whole, the effect of the Carolina may be said to have been beneficial, particularly in the south of Germany, where it moved toward a more humanitarian system of punishments, placing checks on the otherwise virtually unlimited discretion of judicial officers. But its accompanying movement toward national uniformity came at a high price in the North, for the Carolina provided that a conviction could not be obtained upon mere circumstantial evidence. This led to the general introduction of torture to obtain sure proof by confession, a practice not widely followed in the North at the time of the Carolina's promulgation. ${ }^{15}$

\section{Codification in France}

Despite the early start of the Carolina in Germany, it was in France following the Revolution that codification played its most important role on the European continent. Reform, of course, antedated the Revolution in France. ${ }^{16}$ It was in the platform of the Party of the Revolution, however, that the ideas of reform were best expressed: equality, individuality, mitigation of the severity of the penal system, the suppression of discretionary powers of judicial officers to define crimes and assess punishments, the abolition of crimes against religion and private morality, publicity for criminal

13. The City of Ulm, at the Town Assembly at Esslingren in 1523, for example, declared that the Code "tends solely to the disadvantage of the States of the realm . . . " C. VoN BAR, History of Continental Criminal Law 216 (1916).

14. Id.

15. Id.

16. Catherine 11 of Russia encouraged a number of individual philosophers and actually gave instructions for drafting a criminal code. Frederick the Great, influenced by the ideas of the Encyclopedists, began his reign by the abolition of torture. In France itself, Colbert, minister of Louis XIV (1667-70), projected a code, and a beginning was made in a series of royal ordinances. Two other attempts were made under Louis $\mathrm{XV}$, but it was not until after the Revolution that these beginnings bore fruit. See generally C. VON BAR, supra note 13, at 315-19. 
procedure, assistance of counsel, the end of the compulsory oath of the accused, and the institution of the jury. Montesquieu, Beccaria, and Voltaire all called for a reform of the prevailing system of arbitrary criminal justice, and their call was heeded in France.

ln 1793, after the Revolution was underway and at the direction of the Convention, the process of reform began, and Cambaceres brought forth a draft civil code. Out of suspicion of its Roman law influence, however, it was rejected as not being revolutionary; it was felt that an attempt should be made to realize the philosophical idea of simple democratic laws accessible to all citizens and a vote was taken to appoint a committee of philosophers to draw up such a new draft. As might be expected, nothing came of this suggestion, and success had to await a new Justinian.

In 1800 Napoleon, as First Consul, took up the matter with characteristic vigor, appointing a new commission of four. Within four months, a new draft, following many of Cambaceres' proposals, was put together. This code, too, met with political opposition-politics has always played its part. Napoleon responded by reforming the legislative body and, in March, 1804, he obtained the successful approval of the code that today bears his name, and which has served as a model for other codes throughout the world. The civil code was soon followed by codes of civil procedure, commercial law, and, of course, penal law and criminal procedure. ${ }^{17}$

Montesquieu, Beccaria, and Voltaire had called for reform, but it was the ideas of Jeremy Bentham, the English utilitarian, that were used in its implementation. Bentham's works had been translated and published in France in 1802, and his doctrines undoubtedly formed the basis of the new penal code. Nevertheless, the code was at once reactionary and forward looking. Justice was not its aim, save in the requirement that penalties be proportionate. Instead, it rested solely on a need to punish which flowed from the concept of deterrence. Reform of the individual was not even considered. On the other hand,

17. A commission, composed of Vieillard, Target, Oudard, Treillhard, and Blondel, had been appointed under the Consulate to consider the codification of the criminal law. Its report was first considered by the criminal courts, and key issues, formulated by Napolcon himself, were debated in the Council of State. Nevertheless, principally bccause of Napolcon's opposition to the jury, action was suspended for three years. Consequently, the code of criminal procedure was not enacted until 1808, while the penal code was not enacted until 1810 . Neither went into effect, however, until 1811. The government waited until then to put them into cffect, so that a newly reorganized magistrary would be ready to receive them. On the codification efforts of Napoleon, see generally J. Herold, The AGE OF NAPOLEON 146-49 (1963). 
its definition of crimes, while an improvement over the system of unlimited discretion of the Old Regime, still gave too wide a scope to criminality. Barbarous mutilations were also authorized, and its system of imprisonment was a fraud, for there were no penitentiaries appropriate for the various punishments. As a work of codification, though, the code was drawn with simplicity, clearness, and order; under its sentencing provisions, punishments were no longer absolutely fixed, and the important advance of a maximum and a minimum term of imprisonment was also introduced.

In the meantime, a reaction against legislative codification set in along with the disenchantment that followed the abandonment of the simplistic eighteenth-century notion that human reason was adequate and beneficial for every task. The Revolution of Reason had, after all, given way to the Reign of Terror and the rise of Napoleon himself. Indeed, after these events, few men of reason remained optimistic about the nature of man. In the place of the earlier optimism of the school of reason, the more realistic approach of the historical school arose, skeptical as to the efficacy of lawmaking and thoroughly disbelieving in the necessarily good results of codification or reform.

\section{The Highest Achievement: The German Civil Code}

General interest in codification after Napoleon did not revive in Europe until the last quarter of the nineteenth century, when the legislative activity of the German Empire led to a succession of new codes. The most important of these was the German civil code, drafted by a commission appointed in 1874, which consisted of six judges, three lawyers, and two professors. The code went through several drafts, and when a final draft was published, general criticism by all segments of German society was solicited. Every part of the code was subjected to searching criticism, and at the end of three years the controversial parts were brought together and a new commission-composed of eight judges, two lawyers, and one professor - was appointed to draft a code de novo, taking into consideration the criticism and experience obtained from the earlier edition. ${ }^{18}$ When the civil code was published in 1896 , to take effect in 1900 , it was a product of twenty-three years of extraordinarily thorough work, and it serves as a model for the production of an enduring, satisfactory codification. ${ }^{19}$

18. 3 R. Pound 699.

19. For a more complete and fully documented account of the experience with the German Civil Code, see 3 MaltLand, supra note 7, at 474-88. 


\section{Codification at Common Law}

In contrast to this activity on the continent, codification of the common law was first proposed in 1614 by Francis Bacon, then Attorney General, who suggested that the penal laws should be reviewed by a commission "to the end that such as are obsolete and snaring may be repealed; and such as are fit to continue and concern one matter, may be reduced respectively into one clear form of law."20 A series of political controversies, however, intervened and Parliament was dissolved before it could act on Bacon's plan. Bacon then persuaded the King to take the matter up by royal commission. The commission consisted of seven lawyers, including Sir Edward Coke, and although it found some six hundred statutes fit to be repealed, it again failed to affect reform because of political controversy. Consequently, the English common law, by the time of the American Revolution, had never experienced comprehensive codification. Unlike its Roman law rival after the time of Justinian, there was no single source from which its contours could be determined-it was, in Coke's famous phrase, a work of "artificial reason," the meaning of which had to be gathered by long study of statute and text. ${ }^{21}$

\section{Codification in the United States}

Livingston's Code. In the United States, during our formative years, agitation for codification was relatively widespread. It grew out of local hostility toward English institutions and English law in the period after the Revolution and the favorable attitude that existed toward things French that followed the advent of Jeffersonian democracy. It was also the product of the excellent reception given in the United States to the writings of Bentham, particularly by men like Edward Livingston of Louisiana, ${ }^{22}$ the father of the American codification movement.

20. 5 J. Spedding. The Letters and the Life of Francis Bacon 41 (1869).

21. The unsuccessful efforts of Stephen in England and the successful efforts of Macaulay in India, see 3 R. Pound 707-08. are omitted here not out of an attempt to depreciate their value, but because of a limitation of space in this section, and a desire to trace only the direct line of development in the United States.

22. In 1803. at the age of 39, Livingston, the son of a prominent New York family, was both the United States Attorney for New York and the Mayor of the City of New York itself. Following a yellow fever epidemic that year, Livingston suffered serious financial reverses. Consequently, he sold his possessions, resigned his positions, and left New York to seek a new life in Louisiana, where he quickly rose to become a leading member of the bar. See generally Hall, Edward Livingston and his Louisiana Penal Code. 22 A.B.A.J. 191 (1936). 
On February 10, 1820, the General Assembly of Louisiana, in the tradition of French law, passed a historic act providing that there be prepared for the state a comprehensive code of criminal law founded upon the principle of crime prevention; the code was also clearly and explicitly to define all offenses in understandable language and to proportion the various punishments among the offenses defined..$^{23}$ Livingston, a scholar familiar with Roman, comparative, and the common law alike, received the appointment to prepare the new code. Although fire tragically and totally destroyed his first manuscript, Livingston started afresh and produced the work we know today in 1824. The code, however, was not adopted by the state legislature, largely because of the provincial opposition of the Louisiana bar-it was too far ahead of its time. Nevertheless, it gathered the unremitted praise of men like Bentham, Kent, Story, and Marshall. It also formed the basis of a proposed federal penal code later offered by Livingston as a representative in Congress from the state of Louisiana. But like the Louisiana legislature, Congress never acted on Livingston's proposed code.

The Field Code. While Livingston's work did not immediately bear fruit, David Dudley Field's work in New York did. In the New York Constitutional Convention in 1846, Field, another disciple of Bentham, urged a general code, and largely as a result of his advocacy the Constitution of 1847 provided for a commission to undertake procedural reform and codification of the law. ${ }^{24}$ The commission was appointed in 1847, and by 1850 complete codes of civil and criminal procedure were submitted to the legislature. Although the code of civil procedure alone was adopted at that time, in 1857, the legislature again called for codification and Field was appointed commissioner. By 1865 , penal, civil, and criminal codes had been produced, as well as civil and criminal procedure codes; but again Field's work met with less than full acceptance, as only the code of criminal procedure was adopted. The penal and criminal procedure codes, however, were widely adopted elsewhere..$^{25}$

Seldom has one man achieved as much as Field, yet it must be acknowledged that the codes were by no means always well drawn, and often they presupposed too great a knowledge of pre-existing law.

23. 1 The Complete Works of Edward Livingston on Criminal Jurisprudence 1 (1873).

24. N.Y. Const. art. $6, \S 24$ (1846).

25. See 3 R. Pound 709-13. 
Again, as was the case with Livingston's efforts in Louisiana, the task of codification in New York proved to be more than one man could undertake, even with help and eighteen years of tireless work. ${ }^{26}$

\section{The Development of Federal Criminal law}

\section{The Constitutional Basis}

Chronologically, the history of the federal criminal laws might well begin with the Crimes Act of 1790 which defined for the federal government such offenses as treason, piracy, counterfeiting, perjury and bribery in federal court, murder and other crimes on the high seas, and infractions of the law of nations, as well as other offenses in areas subject to federal jurisdiction. ${ }^{27}$ Any examination of the history of federal criminal law, however, must begin with the provisions of the Constitution itself, which are its ultimate bases. "The people of the United States," who brought the new government into existence, assigned to the federal government certain powers and imposed upon it certain limitations. For present purposes, the most important of those powers was that which authorized the Congress "to make all laws ... necessary and proper . ..."28 to the exercise of other powers granted by the Constitution, for it is, in a special sense, upon this provision that the federal criminal jurisprudence rests. Unless a criminal act had some relation to the powers of Congress, or the immediate jurisdiction of the United States, it was a matter which was within the power of the states alone. ${ }^{29}$

Indeed, the implication of the necessary and proper clause for

26. For developments in state penal codification since the Field Code, see G. MUELLER, Crime, law, and the Scholars; A History of Scholarship in american Criminal law (1969).

27. For a more comprehensive treatment of the history of the fcderal criminal law, sec Conboy, Federal Criminal Law, in 1 Law: A Century of Progress 1835-1935, at 294 (1937), upon which I have heavily drawn.

28. U.S. Const. art. I, § 8(cl. 18).

29. As Justice Field observed in United States v. Fox, 95 U.S. 670 (1877):

There is no doubt of the competency of Congress to provide, by suitable penalties, for the enforcement of all legislation necessary or proper to the execution of powers with which it is intrusted . . . Any act committed with a view of evading the legislation of Congress passed in the execution of any of its powers, . . . may properly be made an offence against the United States. But an act committed within a State, whether for a good or a bad purpose, or whether with an honest or a criminal intent, cannot be made an offence against the United States, unless it has some relation to the execution of a power of Congress, or to some matter within the jurisdiction of the United States. An act not having any such relation is one in respect to which the State can alone legislate. Id, at 672. 
federal criminal jurisprudence did not escape the attention of those who feared the ratification of the Constitution. Mason, a delegate to the convention from Virginia, but one who refused to sign the Constitution, argued that this clause would permit the Congress, among other things, to constitute new crimes. To this, a reply was made by Iredell of North Carolina, afterwards associate justice of the Supreme Court, that the Constitution made reference to only a few select offenses "immediately affecting the security, the honor or the interests of the United States at large . . . .30

\section{The Crimes Act of 1790}

In 1789, under the power to "constitute Tribunals inferior to the Supreme Court," 31 Congress passed the first Judiciary Act, which gave the newly created district courts "exclusively of the courts of the several States, cognizance of all crimes and offences that shall be cognizable under the authority of the United States . . . ." 32 In the following year, the Congress passed the first crime act, ${ }^{33}$ which punished offenses against the operations of government and offenses committed on the high seas or against the law of nations-all areas specifically noted by the Constitution. The Act also contained provisions implementing the power, conferred by the Constitution, of exclusive authority over "all places purchased by the consent of the Legislature[s]" ${ }^{\prime 34}$ of the several states-the so-called federal enclaves. The Act of 1790, however, punished few of the common law-type offenses-such as rape, arson, and battery - which were committed in areas beyond state jurisdictional power. This created the grave situation where many crimes ran the actual risk of going unwhipped of justice, and this lack of general common law jurisdiction was described by Mr. Justice Story as a "vexed question." 35

30. P. Ford, Pamphlets on the Constitution of the United States 359 (1888).

31. U.S. Const. art. I, § 8(cl.9).

32. Act of Sept. 24, 1789, ch. 20, $\S 9$, I Stat. 76.

33. Act of April 30, 1790, ch. 9, §§ I-33, I Stat. 112.

34. U.S. CoNST. art. I, \& 8 (cl. 17).

35. The gravity of this situation was indicated by Justice Story in these terms:

Few, very few, of the practical crimes, (if I may so say,) are now punishable by statutes, and if the courts have no general common law jurisdiction, (which is a vexed question,) they are wholly dispunishable. The State Courts have no jurisdiction of crimes committed on the high seas, or in places ceded to the United States. Rapes, arsons, batteries, and a host of other crimes, may in these places be now committed with impunity. I LIFE AND LETTERS OF JOSEPH STORY 297 (W. Story ed. 1851). 


\section{The Common Law Crimes Controversy}

Was it necessary for Congress to specify all the offenses that might be committed against the authority of the United States? A number of the activist members of the early Federalist judiciary did not think specific legislation was necessary. In 1799, Chief Justice Ellsworth, in his famous charge to the Federal Grand Jury of the Circuit Court of South Carolina had, after all, told the jury to indict on the basis of the common law. ${ }^{36}$ But this opinion, as Story indicated, was not universally shared. Jefferson himself was of the opinion that surh an encroachment upon the Constitution made all others theretofore seem as nothing but "mere retail stuff." 37

Story's "vexed question". of 1816 was authoritatively settled by the Supreme Court in United States v. Coolidge. ${ }^{33}$ Although Coolidge settled the issue, it is more accurate to credit United States $v$. Hudson \& Goodwin ${ }^{39}$ with deciding it. Hudson \& Goodwin originated in the Connecticut District Court and was referred by that court, after long delay, to the Supreme Court. The indictment was based on an alleged common law libel, one of many aimed at Jefferson when he was President. All the others Jefferson had succeeded in having dismissed, and Madison, President when the case came on in 1812, was heir to Jefferson's opinions. This no doubt explains why Pinckney, then the Attorney General, declined to argue the case, as did the opposing counsel. Thereupon, Justice Johnson, for the Court, declined to examine how far "an implied power [of any political body] to preserve its own existence. . . is applicable to the peculiar character of our constitution . . . " and disavowed that "the Courts of that Government are vested with jurisdiction over any particular act done by an individual in supposed violation of the peace and dignity of the sovereign power [of the federal government]. The legislative authority of the Union must first make an act a crime, affix a punishment to it, and declare the Court that shall have jurisdiction of the offence." 40

36. I C. Warren, The Supreme Court in United States History 162 (1923).

37. Jefferson commented on the theory in a letter to Pinckney in these terms:

I consider all the encroachments made on . . . [the Constitution] heretofore as nothing, as mere retail stuff compared with the wholesale doctrine, that therc is a common law in force in the United States of which and of all the cases within its provisions. . . . [the federal] Courts have cognizance. It is complete consolidation. Id. at 164.

38. 14 U.S. (1 Wheat.) 415 (18I6).

39. 11 U.S. (7 Cranch) 32 (1812).

40. Id. at 32-34. 
When Coolidge arose four years later, the proceedings were merely perfunctory. Justice Story, in the Circuit Court of the District of Massachusetts, from which the case was referred when the judges were divided, had expressed the opinion that all criminal offenses within the admiralty jurisdiction were cognizable in the circuit court, and in the absence of positive law, were punishable by fine and imprisonment. The Attorney General again declined to argue, in deference to the decision in Hudson, and until it was argued, the former decision was to stand-and that was all. ${ }^{41}$

A few days before, in his opinion supporting Justice Story in Martin v. Hunter's Lessee, ${ }^{42}$ Justice Johnson, after emphasizing the desire "to prevent dissension and collision," had mentioned that "[a]t present, the uncontrollable exercise of criminal jurisdiction is most securely confided to the state tribunals." 43 "Securely confided" it might be, but in this there was no consolation for federal judges. District Judge Peters commented, in a letter written the next month, that under the Coolidge decision he could not carry on the business of his district, since every crime not codified by statute could be committed with impunity. ${ }^{44}$

The difficulty, moreover, continued to recur. In United States $v$. Bevans, ${ }^{45}$ Chief Justice Marshall held that while the Constitution had provided the federal courts with admiralty and maritime jurisdiction, Congress had not, in the statute of 1790 , so exercised that power as to confer on the courts of the United States jurisdiction over "murder committed on board a ship of war, lying within the harbour of Boston

41. Justice Story observed that he did "not take the question to be settled by that case." 14 U.S. ( 1 Wheat.) at 416 . Justice Johnson considered it "to be settled by the authority of that case." Id. Justice Washington would divest himself of all prejudice arising from that case "[w] $w$ henever counsel can be found ready to argue it ...."Id. Justice Livingston was "disposed to hear an argument on the point. This case was brought up for that purpose...." ld. -

42. 14 U.S. (1 Wheat.) 304 (1816).

43. Id. at 377 .

44. Specifically, Judge Peters said:

I cannot carry on the business of my district . . . . Unless some legislative authority be given . . . our. criminal code may be expunged. Treason is defined by the Constitution; but most other crimes are barely named . . . . [O]ur jurisdiction of crimes punishable at common law is excluded. . . I I had little difficulty before . . .; but now my hands are tied, and my mind is padlocked . . . Every crime, not defined in our statutes-murder, rape, all the lesser offences may be committed with impunity in places under the exclusive jurisdiction of the United States . . . . C. WARREN, supra note 36, at 441 (emphasis in original).

45. 16 U.S. ( 3 Wheat.) 336 (1818). . 
. . . ."46 Again, in United States $v$. Wiltberger, ${ }^{47}$ it was decided that manslaughter committed on an American ship in the river Tigris, in China, which being tidal water was not "on the high seas," could not be punished under the act of $1790 . .^{48}$

The Crimes Act of 1825

What Story was not able to do as a Justice he remedied through his friendship with Webster, then Chairman of the House Judiciary Committee. Webster and Story carefully drafted and revised the Crimes Act of $1825,{ }^{49}$ which Webster successfully guided through Congress. The Act of 1825 made several important contributions to federal criminal law. "The high seas" was amplified to include "any river, haven, creek, basin, or bay, within the admiralty and maritime jurisdiction of the United States"; ${ }^{50}$ offenses committed on an American ship "while lying in a port or place" in a foreign country were to be punishable in the same way as offenses committed on the high seas, unless the offender was brought to trial in the foreign country; ${ }^{51}$ and in any of the places ceded by a state to the United States, punishment for crimes committed therein was to be the same as would have been provided for a like offense committed within such state. ${ }^{52}$ The concluding section of the Act, moreover, provided that "[n]othing in this act . . . shall be construed to deprive the courts of the individual states, of jurisdiction, under the laws of the several states, over offences made punishable by this act."

\section{The Revised Statutes of 1877}

From 1825 until the close of the Civil War, the few additions to the list of statutory crimes which were made broke little new ground.

46. Id. at 391 .

47. 18 U.S. (5 Wheat.) $76(1820)$.

48. $I d$. at 105 . The issue also has contemporary significance. Mario J. Escamilia was recently found guilty in the United States District Court for the Northern District of Virginia, of involuntary manslaughter in the shooting death of his supervisor at an arctic weather station. A central question in the trial was the jurisdiction of the United States over Fletcher's Island, an eighteen mile square ice island afloat in the Arctic Ocean. on which the weather station was built. On the return of the verdict, the court frankly noted: "I"m fully conscious of the fact that this ought to be appealed." The Washington Evening Star, May 10, 1971, at 31, col. 3.
49. Act of
50. Id. \& 4
51. Id. $\$ 5$.
52. Id. $\S 3$.
53. Id. § 26 . 
When the Revised Statutes of 1873 were compiled, offenses that were included in the revision were but reminders of the conflict over slavery and secession that had dominated the attention of Congress in the period from 1825 to 1865.54

The work of the revision of 1873-77 derives from a statute of 1866 , in which Congress authorized the appointment of three legally learned persons to bring together in a convenient form all of the statutes then in effect, and to "arrange the same under titles, chapters, and sections, or other suitable divisions." 55 Of the more than fifty-six hundred sections in this revision, the crimes title accounted for two hundred and twenty-seven. Of key importance was the plan adopted for the grouping of offenses which identified the scope of the federal criminal law. This plan was reflected by the chapter headings which included crimes against the existence of government, crimes arising within the maritime and territorial jurisdiction, crimes against justice, crimes against the operations of the government, official misconduct, crimes against the elective franchise and civil rights of citizens, the punishment of accessories, and prisoners and their treatment.

A further, and in the main a correcting and revising, edition containing all amendments made up to the close of the 1877 session of Congress was issued in 1878 , and it served the nation reasonably well for almost thirty years.

\section{The Penal Code of 1909}

When, in 1909, Congress passed an act to codify, revise, and amend the penal laws of the United States, ${ }^{56}$ there was a difference in the naming of chapters, which at once suggests a considerable extension of scope. Many previous offenses were simply carried over, although some of them were considerably enlarged, but new sections were also added, including offenses against the postal service and offenses against foreign and interstate commerce. The revision of 1909 was a much more comprehensive effort than any that had preceded it. In the main, earlier revisions had merely compiled existing statutes, while in this one, Congress labored also to perfect the form. Everything redundant or obsolete was omitted, and such

54. Some offenses were included that had been enacted into law in and before 1820 in connection with Negro slavery, some that were enacted incidentally to the Civil War itself, and some that were sequels to the fifteenth amendment.

55. Act of June 27, 1866, ch. 140, $\$ 2,14$ Stat. 75.

56. Act of March 4, 1909, ch. 321, 35 Stat. 1088 (preamble to chapter). 
changes or additions as were needed to clarify Congressional intention were freely made. There was, it was felt, an imperative demand for clear and systematic compilation. Search for federal statutory law, even if all the Statutes at Large, temporary enactments, and appropriations bills were not examined, had to be made through the 1878 edition of the Revised Statutes, through a first and second supplement, and through volumes thirty-two to thirty-four of the Statutes at Large. It was, therefore, contemplated to supersede all these by a statute which, when completed and enacted, would become the original and authoritative law of the land..$^{57}$

The 1909 revision was prepared by a Special Joint Committee of Congress on the Revision of the Laws, appointed by a concurrent resolution, approved March 2, 1907. Preparation for the Joint Committee's work had been done by the earlier appointment of a statutory revision commission, ${ }^{58}$ whose work was initially limited to revising and codifying the criminal and penal laws of the United States, but which was subsequently enlarged to include "all the laws of the United States of a permanent and general nature . . . ."59

A codification of the criminal law was reported by the Commission on May 15,1901, and copies were sent to various bar associations for consideration and comment. The scope of the proposed codification may be inferred from the comment of a committee of the Association of the Bar of the City of New York that it considered "the proposed great extension of Federal criminal jurisdiction over the whole field of common law and statutory crime within the territorial and maritime jurisdiction of the United States to be unnecessary and very unwise." ${ }^{60}$ The report did, in fact, include, in six subchapters, a great number of proposals new to the federal law

57. The history of the revision substantiates this appraisal. Its necessity was made plain by a passage in the report by the Congressional Joint Committee on the Revision of the Laws which accompanied the presentation of its bill. Referring to enact ments since the revision of 1878, the report commented that since then:

... more laws of a permanent nature have been passed than had been from the time of the adoption of the Constitution down to the time of that revision.

These are scattered through nearly twenty bulky volumes of the Statutes at Large.

They are commingled with a voluminous mass of temporary enactments and are frequently found embodied in appropriation bills, the title and context of which would give no indication of their purport; and the very existence of which is discovered only by the trained lawyer and the painstaking student. S. Rep. No. 10, 60th Cong., Ist Sess. 3 (1909).

58. Act of June 4, 1897, 30 Stat. 58.

59. S. REP. No. 10, supra note 57, at 2.

60. Conboy, supra note 27 , at 313. 
and explained in the margin by reference to laws of the several states. Despite such criticism, the work of the Commission continued and, on March 3, 1905, it was directed to add to its reports any laws enacted since their preparation. ${ }^{61}$ The Commission's final report was required by December 15, 1906, and at that time the result of its labors passed into the hands of the Joint Committee.

The proposed work of codification submitted by the Commission incorporated one hundred seventy-four new sections, twenty-one embodying, and ten creating, new offenses. The Joint Committee's reception of this product, however, was not altogether sympathetic with the assumption of powers by the Commission to go beyond mere codification. ${ }^{62}$ Although some of the proposals were not adopted, largely out of a fear that it might "retard" or "prevent" the work of codification, ${ }^{63}$ the chapter divisions into which it had grouped the laws were retained. Indeed, despite some apparent displeasure with the work of the Commission, great respect was manifested throughout for the legal attainments and the industry of its members. It was, for example, on their suggestion that the chapters on postal laws and on foreign and interstate commerce were included in the Code of 1909. ${ }^{64}$ On January 7, 1908, the Joint Committee reported on the Commission's draft, and submitted a bill which became a. statute to take effect January 1, 1910, known as the Criminal Code of $1909 .{ }^{65}$

\section{The "One People" Concept}

Between the Code of 1909 and the codification of 1948, a number of significant new federal criminal offenses were enacted. Their

61. Act of March 3, 1905, Pub. Res. No. 58-27, 33 Stat. 1285.

62. The Committee observed:

The Commission interpreted its powers under the language of various acts creating it to authorize it to alter and amend what it deemed the imperfections of existing statutes and to embody in its work such legislation as in its judgment was required to supply the inequalities of the existing law. Its recommendations to Congress, based upon this theory, report many of the sections altered in form and expressed in different language; many others so changed as to include different subject matters and many new sections embracing subjects upon which Congress has never attempted before to legislate, but does not exhibit anywhere a simple codification of the existing laws. S. REP. No. 10, supra note 57 , at 2.

63. Id. at 6.

64. As to this last, the Committee said in its report:

The foreign and interstate commerce of this country has assumed proportions so vast, is growing so rapidly, and legislative enactments pertaining thereto are already so numerous that it also seemed proper to collect the penal legislation relative thereto under a distinctive head. Id. at 9.

65. Act of March 4, 1909, ch. 321, 35 Stat. 1088. 
significance may be best understood by prefacing their consideration with a reference to Madison's conception of the scope of the powers of the federal government. In The Federalist, he observed that:

The powers delegated by the proposed constitution to the federal government, are few and defined. Those which are to remain in the state governments, are numerous and indefinite. The former will be exercised principally on external objects, as war, peace, negotiation, and foreign commerce; with which last the power of taxation will, for the most part, be connected. The powers reserved to the several states will extend to all the objects, which, in the ordinary course of affairs, concern the lives, liberties, and properties of the people; and the internal order, improvement, and prosperity of the state."

This limited conception of the role of the federal government stands in sharp contrast, of course, with what as a matter of history has come to pass. For example, in June, 1910, less than six months after the Code of 1909 went into effect, Congress passed the Mann Act, a provision against the "moral misuse" of the facilities of interstate commerce. ${ }^{67}$ The Act was upheld in Hoke \& Economides $v$. United States, ${ }^{68}$ and Mr. Justice McKenna employed expressions that serve as a reminder that since 1872 Congress had been acting intermittently upon a principle which was foreign to Madison's. "Our dual form of government," McKenna observed, "has its perplexities, . . . but it must be kept in mind that we are one people; . . . and the powers [granted to the federal government] . . . are adapted to be exercised, whether independently or concurrently, to promote the general welfare, material and moral." 69

The inference is plain. Lotteries, frauds, circulation of obscene literature, prostitution, and narcotic addiction were all initially well within what Madison had in mind when he commented that the states retained power over the rights of people and the maintenance of the state. As we became not only one people, but one nation, however, the states became unable to exercise their own powers effectively to preserve the "internal order," since their efforts to suppress what the people of the nation saw as national evils were negated when the facilities of the mails or the privileges of interstate commerce were seen to operate. In the judgment of many, these evils were present

\footnotetext{
66. The Federalist No. 45, at 292 (Gideon ed. 1818) (J. Madison).

67. Act of June 25, 1910, ch. $395, \S \S 1-7,36$ Stat. 825 , codified at 18 U.S.C. $\S \S 2421-24$ (1964).

68. 227 U.S. 308 (1913).

69. Id. at 322 .
} 
throughout the nation; since there were federal constitutional powers under which they could be attacked by federal criminal legislation, Congress from time to time made use of them, singly or in combination, to promote the general welfare.

The use of federal power to protect the "general welfare, material and moral," may also be demonstrated by another reference to the Mann Act, and the cases upholding its validity. In Hoke Justice McKenna had held that the interstate commerce power had been rightly used to "promote the general welfare, material and moral," by the suppression of prostitution. In Caminetti $v$. United States, ${ }^{70}$ where prosecution had been brought against the interstate transportation of a woman for the "immoral" purpose of becoming a mistress, however, he felt obliged to dissent. The statute's history, Justice McKenna said, showed that the white-slave law was meant to suppress prostitution, and therefore its provisions should be construed in the sense that prostitution, not "immorality," was the evil against which the Mann Act was directed. ${ }^{71}$ The majority of the Court did not feel such constraint, however, and held that the words "for any other immoral purpose" must be given their natural significance, which would uphold the conviction.

An example of powers employed in combination to.deal with matters of perceived general welfare is the Harrison Act, ${ }^{72}$ which dealt with the control of narcotics. Opium and its derivatives were of foreign origin and therefore articles of foreign commerce, which, it was originally thought, could be dealt with adequately under the commerce power. When this proved ineffective, however, the taxing power was utilized in the Harrison Act to accomplish national narcotic regulation in the years immediately after $1914 .{ }^{73}$

70. 242 U.S. 470 (1917).

71. Id. at $496-503$.

72. Act of Jan. 17, 1914, ch. 9, §§ 1-8, 38 Stat. 275.

73. The history of this development is instructive. Opium had been imported since 1832. By 1870, its use had spread from the Chinese on the Pacific coast to the remainder of the general population. In 1875, California and Nevada realized that control was necessary, and ordinances were enacted in San Francisco and Virginia City. Congress increased the duty on opium to six dollars, then ten dollars, then twelve dollars a pound, but this only led to profitable smuggling, with wider and clandestine distribution of the drug. It was as easily introduced into states that had anti-narcotic laws as into those that did not. In 1909, therefore, Congress decided to prohibit importation of opium, except in such amounts as were required for legitimate use-import, manufacture, and distribution of this supply to be controlled under regulations issued by the Treasury. Act of Feb. 8, 1909, ch. 100, $\S 11-2,35$ Stat. 614. Penalties for violations of the Act were specified, id. $\S 2$, and illicit drugs were to he seized and forfeited 
Crimes connected with robbery from cars and trucks moving in interstate commerce were other logical subjects for federal enactments. But the reason was not quite so obvious when the interstate commerce power was invoked by the Dyer Act ${ }^{74}$ in 1919, for the recovery of stolen automobiles driven across state boundaries. Nor was it so obvious when Congress, fifteen years later, exerted the interstate commerce power against receivers of stolen property, ${ }^{75}$ adding yet again to the lengthening list of federal offenses.

These examples are, of course, only the high points in the history of the development of federal criminal law. Other offenses, traditionally local problems now considered federal, include kidnapping, ${ }^{76}$ threatening to extort money for ransom, ${ }^{77}$ and flight to another state to avoid prosecution or to avoid giving testimony ${ }^{78}$-all enacted under the interstate commerce power. These enactments did not deprive the states of jurisdiction over such crimes, but were rather theoretically designed merely to supplement the effectiveness of the states in dealing with them, and national attention has been rightly and widely attracted to the activities of the federal investigating agencies in pursuit of those who fall within their coverage.

without the necessity of instituting forfeiture proceedings. Id. What developed was that while importers, jobbers, and manufacturers might observe the regulations applying to them. conservation and disposal of the supply for legitimate use was not realized. In 1914, an international convention was arranged and ratified by the Senate. Next, the Harrison Act was passed, setting up an elaborate structure of control under a series of internal revenue items levied under the taxing power.

When the Act of 1909 was under review in Brolan v. United States, 236 U.S. 216 (1915), Chief Justice White had no difficulty in upholding both Congrcss' power to legislate and to "control . . . those things which are essential to make the power existing and operative." Id. at 220. Consequently, the Court quickly dismissed the argument that the police power in respect to the public health, morals, and welfare of the citizens of each state could be exercised only by that particular state, concluding that this position was "so wholly devoid of merit as to be frivolous." Id. at 222. Nevertheless, when the Harrison Act was upheld four ycars later in United States v. Doremus, 249 U.S. 86 (1919), the Chief Justice dissented. He was one of four who refused to admit that production of revenue was the real purpose of Congress under the Act, or that attaching to the taxing power something not itself within federal jurisdiction was sufficient to keep it there for constitutional purposes. Id. at 95 .

74. Act of Oct. 29, 1919, ch. $89, \S \S 1-5,41$ Stat. 324 , codified at 18 U.S.C. $\S \S 2311-13$ (1964).

75. Act of May 22, 1934, ch. 333, $\S 4,48$ Stat. 794, codified at 18 U.S.C. $\$ 2315$ (1964).

76. 18 U.S.C. $\$ 1201$ (1964).

77. Id. $\$ \S 876-77$.

78. Id. $\S 1073$. 


\section{The Revision of 1948}

Thirty-nine years passed between the Code of 1909 and the revision of 1948, a longer period than that between the revisions of 1878 and 1909. Consequently, the need for an updated code was again widely and rightly recognized. ${ }^{79}$ Work was first begun on the new federal criminal code in $1943^{80}$ by the House Committee on Revision and it was enacted in $1948 .{ }^{81}$ ln connection with that effort, some fifteen hundred letters were mailed to the federal judges, United States attorneys, deans of law schools, and presidents of bar associations explaining the revision and asking for advice and assistance. Many of the responding letters contained concrete recommendations for the improvement of the criminal code. These were catalogued, studied, and made available to the revision staff to aid in shaping the revision. ${ }^{82}$

Following introduction of the bill containing the revision ${ }^{83}$ in the Seventy-ninth Congress, copies were sent to every member of Congress, and also to many other persons and organizations to obtain the wise counsel and suggestions of all interested in the administration of the federal criminal laws. The advice of government officials was sought in problems affecting particular departments or agencies, and the lines of communication were kept open as questions and copies of proposed text were submitted to appropriate agencies for comment and suggestion. Naturally, the Department of Justice was the governmental body primarily concerned with a revision of the criminal law, and members of that department provided their input from the first preliminary analysis to the final draft. ${ }^{84}$

Although revision, rather than reform, was the goal of the 1948 effort, the revision staff did not shrink from a perceived need to alter the penal code's internal structure in several significant respects. Initially, the old system of classification was discarded in favor of an alphabetical arrangement already employed in many state codes.

79. See generally H.R. REP. No. 304 , at 3 .

80. Id. (1964).

81. Act of June 25, 1948, ch. 645,62 Stat. 683 , codified at title 18, United States Code

82. H.R. ReP. No. 304, at 4. This was a procedure similar to that followed in the preparation of the German civil code. See notes 18-19 supra and accompanying text.

83. Originally the bill was submitted as H.R. 2200 in the Seventy-ninth Congress, but a more mature bill was introduced in the Eightieth Congress as H.R. 1600, which, in turn, was superseded by H.R. 3190. H.R. REP. No. 304, at 5-6.

84. Id. at 4-5. 
Thus, crimes were classified by chapter-such as arson, bribery, fraud and false statements-and chapters were arranged in a logical sequence. Future growth was provided for by the adoption of a flexible system of numbering which gave each chapter an odd number, leaving the even numbers, as well as space at the end of chapters, to accommodate future congressional action. Repetition was also omitted by assigning to a single initial chapter all general provisions and definitions common to many sections..$^{85}$ lnconsistency in the punishment provision was also remedied by utilizing a twofold approach. First, where it was found that in spite of exact definition of felonies and misdemeanors, court opinions were in conflict because some twenty-nine punishments were inaccurately labeled, the test of the degree of the crime was left to the definition section. Second, where disparities in punishment existed, a master table showing the character of each offense and its punishment was prepared, which eliminated many inequalities and brought uniformity out of the conflicts which had developed over time. Other changes involved the adoption of a clear and uniform writing style, which caused verbose phrases to be pruned, ambiguous terms rewritten, and archaic expressions eliminated. ${ }^{86} 1 \mathrm{t}$ was also found that consolidation of

85. For example, by inserting the word "causes" in the definition of "principals," as codified at 18 U.S.C. $\S 2$ (b) (1964), it was possible to omit that word altogether with such expressions as "aids or abets" and "causes or procures" from many other sections. By defining "United States" and other terms in chapter 1, it was also possible to avoid the use of the same definitions in other chapters. See, e.g., id. § 5 ("United States"), § 6 ("department" and "agency").

86. For example, the definition of a petty offense was reduced from 53 to 30 words without change in substance. See 18 U.S.C. $\S 1(3)$ (1964). Such phrases as "of any kind whatever" were omitted from many sections as redundant. Another example was $\S 656$ to which United States District Judge Emerich B. Freed referred in his review of the revision before the Judicial Conference of the Sixth Circuit. Judge Freed said:

The verbose, involved, and extremely ambiguous sections dealing with embezzlement or misapplication by an officer or employee of a bank are reduced to simple, clear, and unambiguous language. It might be added that no other criminal statute, with the single exception of that covering conspiracy, has been the subject of more numerous judicial interpretations, due largely to the present involved language. Quoted in H.R. REP. No. 304 , at 8.

In the description of offenses, the word "whoever" was used as the first word in each section defining a crime. This style was followed by the revisers of the 1909 Code with good results. Frequently, a number of "whoever" clauses were found, each spelling out a different crime, which would run together in one paragraph. These were set out in separate paragraphs.

Punishment provisions were written in the alternative and minimum terms and fines were omitted. The qualifications "upon conviction" and "hard labor" were deleted as surplusage. 
sections could be made without making fundamental changes in the offenses involved. ${ }^{87}$

Federal criminal law did not, of course, cease to develop after the successful processing of the 1948 revision, ${ }^{88}$ and although legislative developments appeared regularly after the revision, they did little more than carry forward tendencies already manifest in federal criminal jurisprudence. Controversy emerged over the power of Congress to make legislative findings of the jurisdictional aspects of offenses sufficient to permit conviction, with no rcquirement that jurisdictional indicia be satisfied in individual prosecutions. Although circuit courts of appeal split on the necessity of such a showing and its possible constitutional impropriety, for example, under the gun control provisions of Title VII of the Omnibus Crime Control and Safe Streets Act of $1968,{ }^{89}$ the Supreme Court recently decided the issue, in the context of the extortionate credit transactions provision of the 1968 Act $^{90}$ in Perez v. United States, ${ }^{91}$ and established the constitutionality of drafting federal criminal legislation in this fashion beyond further argument.

\section{The ReCOMmendations OF THE COMmission}

Although since 1948, Title 18 has served the nation well, it is now time to consider the need for a new attempt at codification, reform, and revision on the national level. There are, of course, those who will be reluctant to undertake this task, and their arguments opposing re-

87. This was true especially in the case of sections brought into the revision from titles 7 , Agriculture; 12, Banks and Banking; and 15, Commerce and Trade. Good examples of such consolidations will be found in the chapter dealing with embezzlement and theft, where, in one instance, eleven sections were consolidated into one, resulting in a tremendous saving of space and a notable improvement in style and substance. See 18 U.S.C. $\$ \S 641-64$ (1964).

88. New legislation, for example, strengthening the hand of the federal government against the forces of organized crime was enacted in 1961 and 1970. See, e.g.. 18 U.S.C. § 1952 (1964) (travel in aid of racketeering); 18 U.S.C.A. \& 1955 (Supp. Mar. 197I) (gambling business). See generally McClellan, The Organized Crime Control Act (S. 30) or Its Critics: Which Threatens Civil Liberties?. 46 Notre DAme LAw. 55 (1970); Pollner, Attorney General Robert F. Kennedy's Legislative Program to Curb Organized Crime and Racketeering. 28 BROOKLYN L. Rev. 37 (1961); Symposium-Organized Crime, 38 Notre Dame LAw. $627-726$ (1963).

89. 18 U.S.C. $\$ \$ 921-28$ (Supp. V, 1970). Compare United States v. Bass, 434 F.2d 1296 (2d Cir. 1970) (jurisdictional basis required to avoid constitutional doubt) with United States v. Synnes, 438 F.2d 764 (8th Cir. 1971) (not rcquired and constitutional), United States v. Daniels, 431 F.2d 697 (9th Cir. 1970) and United States v. Cabbler, 429 F.2d 577 (4th Cir.), cert. denied. 400 U.S. 901 (1970).

90. 18 U.S.C. $\$ \S 891-96$ (Supp. V, 1970).

91. 402 U.S. $146(1971)$. 
- codification can be expected to differ little from those which have been employed over the years. We can firmly expect to hear it argued that the present criminal code serves well enough in bringing offenders to justice, and that the shortcomings of existing jurisprudence are known and may be dealt with by proper advance preparation. It will also, of course, be suggested that a new code will cause great confusion and uncertainty and will deprive the practicing bar of its accumulated wisdom under the existing law. ${ }^{92}$ Arguments of this character, however, are now of little more than academic value. The need for federal codification, reform, and revision is now beyond meaningful discussion or argument. Indeed, in my judgment, the question of the need was settled by the Congress when it created the National Commission in $1966 .{ }^{93}$ What is of significance today are much different and far more fundamental issues. The scope of the current problem is not whether, but how codification, reform, and revision should be undertaken; this is an area where no issues are settled and all questions are open for debate. It is to the recommendations of the Commission, therefore, that attention must now be directed.

\section{Premises of the Proposed Code}

As an introduction to the specific discussion of the essential features of the proposed Code, it may be helpful to discuss its

92. These arguments were summarized in $\mathbf{1 9 5 0}$ by Professor J. Denson Smith, Director of the Louisiana Law Institute; shortly after Louisiana became the first state to undergo penal codification in this century. Professor Smith observed:

It was claimed that Louisiana had a system of criminal law that was working very well; under it Louisiana had succeeded in establishing a very good record in bringing to the bar of justice offenders against its order; the shortcomings and deficiencies of its system were known and understood and could be reckoned with; the jurisprudence was established; any new system would only multiply many fold whatever confusion existed; a long and laborious, costly and distressing period of uncertainty would be the fruit of adopting a new criminal code. Present also was the belief that experienced practitioners would lose the advantage of the special knowledge of the intricacies of the common law system and would be no better off than the beginner and that distriet attorneys and judges would have to revamp their files of charges, instructions and other forms. Smith, How Louisiana Prepared and Adopted a Criminal Code, 41 J. CrIM. L.C. \& P.S. 125-26 (1950).

Professor Smith also summarized the experience of his state with codification. He observed: Under the Criminal Code of 1942 criminal law administration in Louisiana has been greatly improved. Instead of being produetive of confusion as was claimed it has done much to simplify; instead of creating uncertainty it has brought assurance; and the envisioned difficulties of adjusting to the new system have not materialized. It is perhaps not too much to believe that the outspoken opponents and the enervating skeptics as well would not now return to the old order. Id. at 135 .

93. See note 3 supra. 
framework in more general terms. The keystone of the Code is its treatment of federal jurisdiction. Instead of being a definitional element of each offense, as is presently the case, federal jurisdiction would become a "basis" under which the criminal misconduct becomes prosecutable-similar to the showing of the place where the offense occurred now required to establish state jurisdiction..$^{94}$ Once the jurisdictional aspect is taken out of the offense definition, other basic features of the proposed Code naturally flow. There is, for example, no longer any occasion to retain the present variety of statutes distinguishable only by their respective jurisdictional factors. Offenses may be consolidated and standardized, while the jurisdictional factors upon which federal prosecution may be undertaken can be catalogued and made selectively applicable to each offense. In addition, it becomes possible to grade offenses in terms of compound criminal misconduct-since offenses are no longer distinguishable by jurisdictional factors, it becomes unnecessary to rely upon such undefined concepts as "kill" or "personal injury" to vary the penalty structure. A streamlined sentencing scheme is also facilitated, and each offense may be classified and keyed to a finite number of penalty levels. Finally, once offenses are no longer formulated in terms of their jurisdictional aspect, it is possible to codify a comprehensive set of defenses, and bring into Title 18 offenses now lodged in other titles.

More specifically, the proposed Code has four essential features which dictate its architecture; organization, and scope. Independent of the jurisdictional reach of its various provisions or their definitional scope, rejection of these basic premises would compel wholesale rewriting or possibly rejection of the proposed Code itself as a basis for comprehensive revision. It is important, therefore, to obtain a clear idea of these features so that a discriminating judgment on their wisdom may be made.

The Technique of Drafting. The first of the four essential features is the overall drafting technique. Offenses are succinctly stated-the verbosity of present statutory language, especially in defining matters by enumerated examples, is avoided. The Dyer Act, for example, proscribes theft of motor vehicles, defined to mean "automobile, automobile truck, automobile wagon, motorcycle, or any other self-

94. See, e.g., the classic decision of State v. Hall, 114 N.C. 909 , 19 S.E. 602 (1894), which held that where a North Carolina citizen fired into Tennessee and killed a man, the murder prosecution had to be brought in Tennessee. 
propelled vehicle designed for running on land but not on rails." ${ }^{95}$ The comparable section of the Code, a general theft provision, simply describes the term "property of another."96

This type of simplified drafting avoids the absurdities of a rule of strict construction, which prompted the Supreme Court in McBoyle $v$. United States" to hold that the term "motor vehicles" did not cover airplanes-requiring the Department of Justice to seek amendment of the statute. The contrary approach of present law may also be illustrated by the freight and baggage theft provisions ${ }^{98}$ which make it a crime to asport freight or baggage from interstate shipments by proscribing thefts from nineteen different kinds of facilities, serially enumerating each and concluding with an inclusive phrase outlawing thefts from interstate shipments. The comparable Code provision simply uses the final inclusive phrase..$^{90}$ The drafting of the new Code, therefore, avoids the unnecessary web of litigation and the hyper-technicalities of pleading and proving the precise interstate character of a shipment. ${ }^{100}$

In short, the manner in which offenses are drafted is designed to avoid the need for extensive cataloguing of terms for definitional purposes. This is made possible principally by a fundamental innovation-restating the rule of strict construction to mean construction in light of purpose. ${ }^{101}$ The Code is explicit in directing that its provisions be construed to achieve its codified ends-for example, the assurance of public safety through the "vindication of public norms by the imposition of merited punishment" 102 and the provision of "fair warning of what is prohibited." 103 Repetitious definitions are specifically avoided by providing that the term

95. 18 U.S.C. § 2311 (1964).

96. PROPOSED CODE $§ 1732$.

97. 283 U.S. 25 (1931).

98. 18 U.S.C. $\$ 659$ (1964).

99. Proposed CODE $§ 1732$. The final inclusive phrase is "property which is the subject of the offense is moving in interstate or foreign commerce or constitutes or is part of an interstate or foreign shipment." The phrase is used to define a jurisdictional base in id. $\S 201$ (i), which is one of the jurisdictional bases of the Code's theft provisions. See generally id. $\$ 1740(1)$.

100. Compare United States v. D'Antonio, 342 F.2d 667 (7th Cir. 1965), United States v. Wora, 246 F.2d 283 (2d Cir. 1957) and Tingley v. United States, 34 F.2d 1 (10th Cir. 1929), cert. denied, 280 U.S. 598 (1930) with United States v. Manuszak, 234 F.2d 421 (3d Cir. 1956). Sec note 89 supra and accompanying text.

101. "[T] he provisions of this Code are intended, and shall be construed, to achieve the following objectives . . . Proposed CODE $\S 102$.

102. Id. § 102(a)(i).

103. Id. $\S 102(\mathrm{~b})$. 
"includes," used in various Code offenses, is to be read as if the phrase "but is not limited to" is also set forth. ${ }^{104}$ Consequently, by the technique of drafting simply, a more rational penal policy can be implemented with confidence that it will not be frustrated in the courts by the inherent ambiguity of human language. ${ }^{105}$

The Treatment of Federal Jurisdiction. The second of the essential features of the proposed Code is its treatment of federal jurisdiction, ${ }^{106}$ which is, as 1 have noted, the keystone of the suggested reform. Alone among the four basic premises, its rejection would require forsaking the present form of the Code as even a work-basis for a new codification.

The framework underlying the Code's use of federal jurisdiction is the following: federal penal laws are defined with a focus on punishing misconduct within the federal jurisdiction, rather than, as is often now the case, some interference with a jurisdictional factor itself. An illustration will make this important distinction clear. Under the present mail fraud statute, ${ }^{107}$ the offense is written, and its "gist" has been accurately perceived not as fraud punishable by the federal government because its mails are used, but as a sullying of the federal sovereign by depositing fraud-related materials in its mails. ${ }^{108}$ Consequently, each mailing is a separate offense, although it was done in execution of a single fraud. ${ }^{109}$ Yet the mailing of one letter in one fraudulent scheme and its consequent defrauding of ten victims remains only one offense punishable by a maximum of only five years, regardless of the enormity of the fraud perpetrated. Finally, under present law, the government must prove that the defendant at least contemplated that his fraud would be committed by use of the mails. "Under the proposed Code, however, the offense is conceived and formulated as fraud. Use of the mails becomes the jurisdictional

104. Id. § 109(r).

105. Justice Johnson in Martin v. Hunter's Lessee, 14 U.S. (1 Wheat.) 304 (1816) aptly stated the difficulty with words: "Language is essentially defective in precision; more so than those are aware of who are not in the habit of subjecting it to philological analysis." Id. at 374.

106. The jurisdictional underpinnings of the proposed Code are contained in Proposed CODE $\$ \S 201-12$.

107. 18 U.S.C. $\S 1341$ (1964).

108. E.g., Atkinson v. United States, 344 F.2d 97, 98 (8th Cir.), cert. denied, 382 U.S. 867 (1965); Bozel v. United States, 139 F.2d 153, 156 (6th Cir.), cert. denied, 321 U.S. 800 (1943).

109. Wood v. United States, 279 F.2d 359 (8th Cir. 1960); Becker v. United States, 91 F.2d 550 (9th Cir. 1937).

110. United States v. Kellerman, 431 F.2d 319 (2d Cir.), cert. denied, 400 U.S. 957 (1970). 
base under which the offense may be federally prosecuted, with the consequence that each of the aspects of the present law just mentioned is reversed.

In shifting the focus of federal penal statutes from jurisdiction to the underlying misconduct as the basis of the criminal offense, the proposed Code effects a major reform of most of the older Title 18 provisions by generalizing the policy underlying many of the statutes enacted during the last decade. Thus, Title 18's long standing provision proscribing the intimidation of witness-informants ${ }^{111}$ makes that offense punishable by a maximum of only five years in jail, even though the intimidation may have ultimately taken the form of murder. In contrast, the 1968 amendment proscribing intimidation of citizens in the exercise of their civil rights, ${ }^{112}$ changed the maximum penalty from one year to life imprisonment for intimidation by murder. The proposed Code, therefore, standardizes a treatment of federal offenses sometimes, but not always, found in present law-a goal toward which the Congress has been gradually moving. ${ }^{13}$

This reform in the treatment of jurisdiction and criminal conduct is implemented by stating the element of federal jurisdiction, called a jurisdictional "base," separately from the definition of the offense which solely defines the misconduct involved. This is done by defining the offense ${ }^{114}$ and then itemizing in a separate subsection the jurisdictional circumstances under which federal prosecution can be undertaken. ${ }^{115}$ The most convenient way to visualize this is to imagine that the jurisdictional factors in each of the robbery and burglary offenses ${ }^{116}$ are taken out, leaving five formulations of the offense of

111. 18 U.S.C. $\$ 1503(1964)$.

112. Id. \& 242 (Supp. V, 1970).

113. Another illustration of the standardization of treatment may be found in Title 18's bank robbery statute, 18 U.S.C. $\S 2113(1964)$, in which punishment is keyed to the underlying misconduct - twenty years for the basic offense, id. $\$ 2113(\mathrm{a})$, twenty-five years if committed by assault, $i d$. $\S 2113(\mathrm{~d})$, and deatb if by murder or kidnapping, id. $\S 2113(\mathrm{e})$-not to an interference with the federal sovereign's jurisdictional base (the Federal Deposit Insurance Corporation). In contrast, id. $\S 1952$ (racketeering), enacted in 1961, followed a different routc in attacking organized crime. Each crossing of state lines was made an offense punishable by no more than five years, even though the racketeer ultimately perpetrated only one or more massive arsons, heinous extortions, or murder itself. Id. $\S$ 1952(a). The proposed Code adopts the format of $i d$. $\S 2113$, and keys punishment to the underlying conduct. For example, arson is defined as a class B crime, Proposed CODE $\$ 1701(\mathrm{I})$, and therefore carries a maximum penalty of fifteen years, id. $\S 3201(1)(b)$, whereas murder is a class A crime, id. $\S 1601$, and carries a maximum penalty of thirty years. id. $\S 3201$ (1) (a). See FINAL REPORT 285-87.

114. See, e.g.. PROPOSED CODE $\S 1721$ (1) (robbery).

115. See, e.g., id. $\S 1721$ (4).

116. 18 U.S.C. \& $2113(1964)$. 
robbery. These "pure" offenses, separated from their jurisdictional factors, are then consolidated and the elements standardized. What emerges is one offense-robbery. The various jurisdictional factors are then picked up, catalogued, and included in a subsection itemizing the jurisdictional circumstances or "bases" under which the offense of "robbery" may be federally prosecuted. The jurisdictional bases for robbery would be the special maritime and territorial jurisdiction, ${ }^{117}$ property of the United States, ${ }^{118}$ Federal Deposit Insurance Corporation banks, ${ }^{119}$ and the mails. ${ }^{120}$ Instead of setting forth the jurisdictional bases in haec verba in each jurisdictional subsection, however, they are catalogued in a general jurisdictional section $^{121}$ with selective cross reference made to this provision in the jurisdictional subsections to the various offenses as a simplified drafting technique. This is little more than an economy measure to avoid prolixity by the constant recitation of jurisdictional bases common to scores of offenses. Some offenses in the proposed Code, of course, are inherently federal and so there is not always a need for a separate jurisdictional subsection. ${ }^{122}$ In addition, there are selected instances where offenses have unique jurisdictional bases which must be set out in specially applicable sections. ${ }^{123}$

Several key results naturally flow from the proposed Code's treatment of federal jurisdiction. First, definitions of offenses can be consolidated and standardized. Thus, in the illustration already given, the Code's section on robbery ${ }^{124}$ telescopes the robbery of banks ${ }^{125}$ and mails and other federal property, ${ }^{126}$ as well as robbery "affecting commerce." ${ }^{227}$ The end result is that the various anomalies in the present proliferation of robbery statutes are obviated. ${ }^{128}$

117. Id. $\S 2111$.

118. Id. \$ 2112.

119. Id. \& 2113 .

120. Id. $\$ 2114$.

121. Proposed Code $\S 201$.

122. See, e.g., id. $\S 1112$ (espionage); id. §§ $1401-09$ (tax); id. \$1411 (smuggling); id. $\S \S 1501-16$ (civil rights); id. $\S 1756$ (bankruptcy fraud).

123. See, e.g., id. $\S 1740(4)$ (setting out the jurisdictional bases for theft offenses); id. $\S 1740(\mathrm{e})$ (pertaining to depredations of employee benefit plans); id. $\S 1740(4)(\mathrm{h})$ (small business investment corporations); id. $\S 1740(4)(\mathrm{k})$ (the funds of common carriers); id. $\S 1740(4)(I)$ (economic opportunity funds).

124. Id. $\S 1721$.

125. 18 U.S.C. $\S 2113(1964)$.

126. Id. $\$ 2114$.

127. Id. § 1951(a).

128. See, e.g., id. $\S 1951$ (b)(1) ("unlawful taking or obtaining of personal property from 
Second, since the focus of the statutes is on the criminal misconduct, not the breach of a federal jurisdictional factor, punishment can be proportionate to the conduct rather than scaled to the jurisdictional aspect. Thus, interstate travel with intent to commit arson ${ }^{129}$ is presently punishable by a maximum of five years imprisonment, although the arson resulted in the destruction of an entire building. Under the proposed Code, however, this conduct would be punishable by up to fifteen years. ${ }^{130}$

Third, utilizing the proposed Code, the prosecution need no longer prove that the defendant had knowledge that he was trespassing upon an area subject to the control of the federal sovereign-for example, at the time an individual crossed state lines he intended to incite a riot $^{131}$ or had a purpose to engage in prostitution. ${ }^{132}$ Instead, under the proposed Code the offense becomes inciting to riot ${ }^{133}$ or promoting prostitution, ${ }^{134}$ subject to prosecution by the federal government if the defendant travelled interstate in its commission or consummation.

Present federal law, of course, handles the question of knowledge of the federal aspect of the crime in an inconsistent fashion. Indeed, it is possible to say that the requirement apparently follows no discernable course from provision to provision. More often than not, knowledge is not required, but when it is, the requirement does not seem to be rooted in any defensible rationale. Often it is little more than an accident of statutory draftmanship. Thus, sometimes it is required, ${ }^{135}$ other times it is not, ${ }^{136}$ and cases under some provisions are actually in conflict. ${ }^{137}$ The requirement of knowledge, in short,

the person . . . against his will"); id. $\S 2111$ ("by force and violence, or by intimidation, takes"); id. § 2112 ("robs"); id. § 2114 ("assaults . . . with intent to rob. steal, or purloin").

129. 18 U.S.C. $\$ 1952$ (1964).

130. PROPOSED CODE $\$ \S 1701(1), 3201(1)(b)$.

131. 18 U.S.C. $\$ 2101(\mathrm{a})$ (1964).

132. Id. $\S 2421$.

133. PROPOSED CODE $§ 1801(1)$.

134. Id. \& $1841(1)$.

135. United States v. Kellerman, 431 F.2d 319, 322 (2d Cir.), cert. denied, 400 U.S. 957 (1970) (mail fraud, 18 U.S.C. $\$ \S 1341-42$ (1964)); Hall v. United States, 235 F.2d 248 (5th Cir. 1956) (assaulting federal officer, 18 U.S.C. $\$ 111$ (1964)); United States v. Bell, 219 F. Supp. 260 (E.D.N.Y. 1963) (assaulting federal officer, 18 U.S.C. $\S 111$ (1964)).

136. United States v. Miller, 379 F.2d 483, 486 (7th Cir.), cert. denied, 389 U.S. 934 (1967) (travel in aid of racketeering, 18 U.S.C. $\$ 1952$ (1964)); United States v. Kierschke, 315 F.2d 315, 317-18 (6th Cir. 1963) (transportation of stolen property, 18 U.S.C. $\S 2314$ (1964)).

137. Compare Burke v. United States, 400 F.2d 866, 868 (5th Cir. 1968), cert. denied. 395 U.S. 919 (1969) (assault upon a federal officer, 18 U.S.C. $\S 111$ (1964)-need not know officer was federal) with United States v. Bell, 219 F. Supp. 260 (E.D.N.Y. 1963) (knowledge that 
frequently serves as a "technicality" that permits a "guilty" offender to "get off." 138 This muddle would be clarified in the proposed Code by simply eliminating the knowledge requirement.

Fourth, the proposed Code would eliminate the multiplication of offenses that result from the existence of multiple jurisdictional bases. ${ }^{139}$ Thus, theft of government property from the mail on a military reservation would no longer be three offenses, ${ }^{140}$ but would instead be one ${ }^{141}$ with three jurisdictional bases-federal enclave, ${ }^{142}$ United States mails, ${ }^{143}$ and property of the federal government ${ }^{144}$-the proof of any one being sufficient for the conviction of the offense of "theft."

Additionally, the definitions of offenses are framed in a fashion consistent with the terms of international treaties for extradition. Presently, serious problems are encountered when the United States desires to extradite a defendant from a foreign country for a federal crime, since the factor of federal jurisdiction is formulated as an element of the crime itself. ${ }^{145}$ Most international extradition treaties, however, provide only for specified criminal misconduct and do not afford extradition for jurisdictional trespasses. ${ }^{146}$ Thus, where extradition is desired for mail fraud ${ }^{147}$ it is not possible because our courts have rightly stated that the "gist of the offense" is.the use of

officer was lederal essential). The most recent treatment of the question is in Goodwin v. United States, 440 F.2d 1152 (3d Cir. 1971) (no knowledge required).

138. See, e.g., United States v. Barrow, 363 F.2d 62 (3d Cir. 1966), cert. denied, 385 U.S. 1001 (1967). The recent trial of David Poindexter, for harboring and concealment, under 18 U.S.C. $\S 1071$ (1964), of Miss Angela Davis while knowing federal warrants had been issued for her arrest is illustrative. Aecording to newspaper reports, the jury apparently returned a notguilty verdict since they were unwilling to infer from circumstantial evidence alone that Poindexter had knowledge of the outstanding federal as opposed to state warrants in connection with the death of a California judge. See N.Y. Times, Apr. 13, 1971, at 1, col. 7; Apr. 8, 1971, at 47, col. 1; Apr. 6, 1971, at 43, col. 1 .

139. PROPOSED CODE $\S 205$.

140. Compare id. $\S 1732$ (theft) with 18 U.S.C. $\S 2111$ (territorial jurisdiction), id. $\S 2112$ (government property) and id. $\S 2114$ (mail).

141. Proposed Code $\S 1432(a)$.

142. Id. $\$ \S 1740(1), 201(\mathrm{a})$.

143. Id. $\S \S 1740(1), 201(f)$.

144. Id. $\S \S 1740(1), 201$ (d).

145. E.g., In re Lamar, [1940] 2 W.W.R. 471, 477 (Can. 1940) (mail fraud not extraditable as fraud); 6 M. Whiteman, Digest of International Law 775, 790 (Dep't of State Pub. No. 8350 (1968)).

146. See generally W. Bishop, INTERnational Law 367 (1953); 4 G. Hackworth, Digest of INTERnational Law 33 (Dep't of State Pub. No. 1756 (1942)).

147. 18 U.S.C. $\S 1341$ (1964). 
the mails, not the fraud, ${ }^{148}$ and though a treaty may permit extradition for "felonious fraud," it often does not provide for extradition for mailing a letter pursuant to a scheme to defraud. ${ }^{149}$ This is a result that may be justified among lawyers for reasons intelligible only to themselves, but as a matter of social policy, it is absurd.

Finally, the proposed Code contains a congressional mandate for restraint in the exercise of federal jurisdiction where it overlaps with local authority ${ }^{150}$ - a key item in the Code's attempt to reach a reasonable balance between federal and local power in the criminal justice area. The proposed Code, having consolidated offenses and itemized in one place the principal reaches of modern federal criminal jurisdiction for each offense, makes visible for the first time the considerable, and possibly imprudent, scope of present federal jurisdiction. Accordingly, the proposed Code contains an introductory section, which for the first time, expresses the will of Congress that federal prosecution should not be undertaken simply because federal jurisdiction exists. ${ }^{151}$ Thus, the offense should be deferred to local authorities unless there is a "substantial Federal interest" in its prosecution, which includes a "serious" offense where interstate aspects of the case impede local law enforcement, ${ }^{152}$ or an offense is associated with organized crime, ${ }^{153}$ or local law enforcement has been corrupted. ${ }^{154}$ This section is intended, therefore, to afford a vehicle for the Congress to express itself on the proper role of the federal sovereign in the executive and judicial enforcement of the laws enacted by it, rather than to continue to permit ad hoc resolution of these fundamental legislative policy matters by the varying sensibilities of judges, prosecutors, and investigators.

The Sentencing Scheme. The third essential feature of the proposed Code is its new scheme of sentencing, ${ }^{155}$ the key features being its streamlined character, its assumption of some type of appellate review of sentences, and its establishment of standards for the imposition of long prison terms. The proposed Code takes the eighteen different maximum prison terms and fourteen different fine

\footnotetext{
148. See note 108 supra and accompanying text.

149. See generally note 146 supra.

150. PROPOSED CODE $§ 207$.

151. Id.

152. Id. §207(a).

153. Id. $\S 207$ (d).

154. Id. $\S 207(\mathrm{e})$.

155. Id. $\$ \S 3001-601$.
} 
levels found in Title 18 alone and standardizes them into essentially six. This is done by classifying each offense as either one of three classes of felonies, ${ }^{156}$ one of two classes of misdemeanors, ${ }^{157}$ or as an infraction, ${ }^{158}$ with standard penalty levels established for each. ${ }^{159}$ By the adoption of this systematization, a consistent proportionality among offenses and penalties may be achieved.

The proposed Code's sentencing scheme is predicated on the concept of appellate review, ${ }^{160}$ although its scope and manner of implementation were not resolved by the Commission. ${ }^{161}$ Thus, guidelines are formulated for imposing sentences in the upper ranges of authorized maxima, ${ }^{162}$ judicially imposed minima, ${ }^{163}$ and the grant or denial of probation. ${ }^{164} \mathrm{~A}$ variation of the scheme to bring standards into a previously standardless area is the requirement of the Code that the judge simply set forth his reasons for granting, for example, a defendant an unconditional discharge, ${ }^{165}$ imposing a consecutive sentence, ${ }^{166}$ or meting out a higher sentence on resentencing. ${ }^{167}$

There are also several innovations in the area of parole. After the first year of imprisonment, release by the parole board is to be determined according to enumerated criteria, including whether the defendant, if he were released, would violate the conditions of his parole. ${ }^{168}$ After service of five years or two thirds of any sentence, nevertheless, the defendant must be released, except where in the

156. Id. § 3002(1).

157. Id. § 3002(2).

158. Id. § 3002(3).

159. Id. §§3201(1), 3301(1).

160. The proposed Code would achieve appellate review by amending 28 U.S.C. $\S 1291$ (1964), with a final sentence which would read as follows: "Such [appellate] review shall in criminal cases include the power to review the sentence and to modify or set aside for further proceedings." See Final Report 317.

161. FINAL REPORT 317.

162. Proposed CODE $\S 3202(1)$. The Code utilizes the same criteria used in Title $X$ of the Organized Crime Control Act of 1970, Pub. L. No. 91-452. See Final Report 290. Section 3202 also employs the presence of "dangerousness," Proposed CODE $\$ 3202(2)(e)$, or a "mentally abnormal aggressive defendant," $i d . \S 3202(2)(c)$ as factors in the sentencing scheme. This would achieve legislatively what Title $\mathrm{X}$ did judicially-proportionality between the various terms. FinAL REPORT 290. On the scope of Title X, see McClellan, supra note 88, at 146.88 .

163. Proposed CODE $\S 3201(3)$.

164. Id. § 3101 .

165. Id. § 3105 .

166. Id. \& 3204.

167. Id. $\S 3005$.

168. Id. \& 3402(1). 
judgment of the parole board he poses a high risk of serious criminality while on parole. ${ }^{169}$ Most importantly, each sentence to imprisonment of more than six months must contain a mandatory parole component. ${ }^{170}$ The purpose of this provision is to maintain control of hardened offenders after their initial release from prison. Under present law an anomolous situation has occurred-the hardened offender serves the maximum of his sentence, then is released without any restraint, while the less dangerous offender is released earlier, but subject to supervision.

Other pertinent provisions of the sentencing scheme establish a recidivist provision for misdemeanants ${ }^{171}$ and retention of split sentences with a provision for intermittent service of jail terms. ${ }^{172}$ Organizations-labor unions and corporations-can also be required, as part of a sentence, to give notice of their misconduct to possible victims ${ }^{173}$ irrespective of the ordinary fine available, and a defendant may be sentenced to a fine up to twice the gain or loss occasioned to his victim by the misconduct. ${ }^{174}$ On the issue of minimum mandatory sentences, the Code's statutory text abandons them, although the Report of the Commission notes that a substantial number of commissioners favored a scheme of presumptive minimum mandatory sentences for certain offenses-for example, wholesaling in narcotics and using a gun to commit a felony. The judge would be statutorily directed to sentence a defendant to at least a modest prison term in the usual case, and required to state his reasons for not imposing such a sentence where he felt the case was unusual. All of these provisions, again, rely upon an assumption in the sentencing scheme of appellate review.

The Technique of Grading. The last of the four essential features of the proposed Code is its use of an ancillary or "piggyback" means for achieving appropriate sentence grading where compound offenses are committed. "Piggyback" grading means that crimes against persons and property occurring in the course of another federal offense become federally prosecutable as related offenses. This technique may be illustrated by again noting that under present law, ${ }^{175}$

\footnotetext{
169. Id. \& 3402(2).

170. Id. § $3201(2)$.

171. Id. $\S 3003$.

172. Id. $\S 3106$.

173. Id. $\S 3007$.

174. Id. $\S \S 3001(4), 3301(2)$.

175. 18 U.S.C. § 1503 (1964).
} 
as well as the proposed Code, ${ }^{176}$ intimidation of a federal judge is punishable by five years imprisonment. If the intimidation takes the form of murder, prosecution may be had under the proposed Code for the "murder" as well as the "intimidation." 177

This technique of grading is not new to federal criminal jurisprudence, but is simply a generalization of a scheme idiosyncratically found in many present federal offenses. For example, in the present bank robbery statute ${ }^{178}$ the basic offense of bank robbery is punishable with a maximum of twenty years, ${ }^{179}$ but the maximum may be increased up to twenty-five years if assault occurs in the course of the bank robbery, ${ }^{180}$ or up to death if there is a murder or kidnapping in the course of such robbery. ${ }^{181}$ The constitutionality of this ancillary or "piggyback" technique, moreover, has been uniformly upheld by the courts where offenses have involved compound aspects of criminal conduct. ${ }^{182}$

The "piggyback" technique of grading under the proposed Code provides a rational and uniform means of grading federal offenses, for scaling the relative seriousness of misconduct integral to the commission of a "basic" offense, and for achieving a clear proportionality where compound qualities are present in criminal misconduct. The variety of the present means of achieving the same result which sometimes create more problems than they solve can, therefore, be eliminated. Present provisions, for example, denote the factors aggravating an offense but, more often than not, fail to define the $m,{ }^{183}$ and rarely are the aggravating factors formulated by definition in terms of another offense. ${ }^{184}$ In addition, the present

176. Proposed Code $\$ 1366$.

177. See the related discussion at notes 11.1-13 supra and accompanying text.

178. 18 U.S.C. \& 2113 (1964).

179. Id. § $2113(\mathrm{a})$.

180. Id. $\S 2113(\mathrm{~b})$.

181. Id. $\S 2113$ (e). See also id. $\S 34$ (destruction of aircraft and motor vehicles, or their facilities, accompanied by death of any person); 18 U.S.C.A. \$ 844(d) (Supp. Mar. 1971) (interstate transportation of explosives); 18 U.S.C. § 1201 (1964) (kidnapping); id. § 1751 (Supp. V, 1970) (crimes against the President).

182. Clark v. United States, 184 F.2d 952, 953 (10th Cir. 1950), cert. denied, 340 U.S. 955 (1951); Gilmore v. United States, 124 F.2d 537, 540 (10th Cir.), cert. denied, 316 U.S. 661 (1942).

183. See, e.g., "assault," which is undefined in 18 U.S.C. $\S 2113$ (d) (1964); "personal injury" and "if death results" in 18 U.S.C.A. \$ 844(d) (Supp. Mar. 1971); "kills" in 18 U.S.C. $\$ 1751$ (Supp. V, 1970).

184. This was done, for example, in 49 U.S.C.A. $\$ 1472(\mathrm{k})(1)$ (Supp. Mar. 1971) where assault, as defined in 18 U.S.C. $\S 113(1964)$, occurs in the course of an airplane obstruction. 
means of grading are legally vulnerable, since they are often ambiguous, if not unconstitutionally vague-for example, the threshold crime of one provision ${ }^{185}$ is stated to be the transportation and receipt of explosives, but the offense is then graded according to whether "personal injury" or "death" results. "Results" from what? "The transportation or receipt" or the subsequent deployment of the explosive? And how "result?" From fortuity, negligence, or recklessness?

Under the proposed "piggyback" technique of grading, the "kill" and "death" of present law become the fully defined crimes of "murder" and "homicide," while the "personal injury" and "life in jeopardy" of present law become the crime of "assault." Problems with "result" are avoided by requiring only that the assault or homicide occur in the course of the commission of the underlying offense. Consequently, unnecessary problems with the troublesome issue of causation are obviated.

Although other special techniques of grading are also employed in the proposed Code, only two warrant comment. In some instances, whether given misconduct is a felony or a misdemeanor is to be determined by the judge at sentencing, depending upon whether the defendant can establish certain factors by a preponderance of the evidence. ${ }^{86}$ Second, the decision to bring into Title 18 all federal felonies results in another grading implication-crimes in other titles of the United States Code cannot be punishable by more than misdemeanor penalties. To illustrate, the proposed Code's offense of draft evasion ${ }^{187}$ proscribes avoiding the draft by failure to register, failure to report, or refusal to submit for induction or civilian work, while the purely prophylactic provisions of present law 188 - such as failure to notify the board of a last known address, which under the proposed Code would remain in Title 50-are made misdemeanors. ${ }^{189}$

185. 18 U.S.C.A. § 844(d) (Supp. Mar. 1971).

186. See.e.g.. PRoposed CODE § 1822(2) whieh provides, with regard to drug offenses, that the act shall be a misdemeanor if the defendant can show he did not act for profit, to further commercial distribution. or for transfer to a juvenile. $/ d$. $\S 1001(3)$ likewise provides that an attempt shall be graded the same as the completed offense unless defendant shows that his conduct did not achieve proximity to commission of the crime.

187. Id. § 1108.

188. 50 U.S.C. App. § 462 (1964).

189. By operation of PROPOSED CODE $\S \S 1006$ and 3006. 


\section{The Relation of the Code to Present Law}

It is not, at the present time, possible to assess what impact the proposed Code will have upon the federal system of criminal justice were it to be implemented in its present form with its various policy judgments. Some tentative conclusions may, however, be drawn concerning the relation of the proposed Code to present law, and this can give us some idea of what that impact might be. From such statistics as are readily available, ${ }^{190}$ the ten most frequently prosecuted federal offenses, in approximate order of frequency, are the Dyer Act, ${ }^{191}$ illegal re-entry by deported aliens, ${ }^{192}$ narcotics, ${ }^{193}$ selective service violations, ${ }^{194}$ moonshining, ${ }^{195}$ postal depredations, ${ }^{196}$ interstate transportation of forged money orders, ${ }^{197}$ bank robbery, ${ }^{198}$ theft from interstate shipment, ${ }^{199}$ and bank embezzlement. ${ }^{200}$ Prosecution under these statutes comprises over fifty percent of the criminal business of the federal courts, and, in all likelihood, a similar devotion of investigative and correctional resources.

The character of some of the major differences between several present Title 18 sections and those suggested by the proposed Code are enlightening. In half of these statutes there is little change-for example, between the Dyer Act ${ }^{201}$ and corresponding Code provisions ${ }^{202}$ the only significant differences are that the proposed Code codifies the judicially fashioned meanings of "stolen" in present law, ${ }^{203}$ and the unlawful takings of motor vehicles are graded as

190. See generally Report of the Director of the Administrative Office of the United States CourTs 255-57, 304-06 (1969). The Subcommittee on Criminal Laws and Procedures is now attempting to secure from the Administrative Office illustrative data on the relation between the proposed Code and the processing of offenses under present law. It is hoped that this data can be included in hearings to be held by the Subcommittee in the Fall of 1971 .

191. 18 U.S.C. $\$ 2312$ (1964).

192. 8 U.S.C. § 1326 (1964).

193. Comprehensive Drug Abuse Prevention and Control Act of 1970, Pub. L. No. 91-513, $\S 401$.

194. 50 U.S.C. $\S 462$ (1964).

195. 26 U.S.C. $\$ 5601$ (1964).

196. 18 U.S.C. $\S \S 1708-09$ (1964).

197. Id. § 2314 (Supp. V, 1970).

198. Id. § 2113 (1964).

199. Id. $\$ 659$ (Supp. V, 1970).

200. Id. § 656 (1964).

201. Id. $\S \S 2311$ et seq.

202. PROPOSED CODE $\S 1731$ et seq.

203. This is done by codifying the various meanings of "stolen" into three provisions: one covering vehicles taken with intent to deprive the owner, id. $\$ 1732$, one covering the 
felonies or misdemeanors depending upon the value of the car, its unauthorized use, or the loss measured by the restoration required. ${ }^{204}$ With respect to immigration violations under present law, ${ }^{205}$ comparison with comparable Code provision ${ }^{206}$ discloses that the offenses are identical, except that the requisite culpability in present law is codified and the current separate offense of being found in the United States after prior deportation is formulated as a presumption that if an individual is found in the United States after having been previously deported he is presumptively guilty of the offense of entering the United States illegally. ${ }^{207}$ Current prosecutive and sentencing policy, ${ }^{208}$ moreover, is codified by grading the offense as a felony if there was a prior deportation and it was for a felony of moral turpitude ${ }^{209}$ or it was a third violation, ${ }^{210}$ otherwise, it is graded a misdemeanor. ${ }^{211}$

As in the firearms area noted below, ${ }^{212}$ the proposed drug provisions ${ }^{213}$ rely for complete definition upon an assumed regulatory scheme that would appear elsewhere in the federal code-for example, in the Comprehensive Drug Abuse Prevention and Control Act of $1970,{ }^{214}$ enacted while the Commission deliberated over these provisions. Although the Commission expressed no preference for the proposed provisions over those found in the Comprehensive Drug Act of $1970,{ }^{215}$ it did recommend that the penalty for possession of marihuana be reduced to that of an infraction, which would embrace only a fine with no possibility of imprisonment, ${ }^{216}$ a result contrary to the provision in the Comprehensive Drug Act of 1970 allowing incarceration for up to one year. ${ }^{217}$

unauthorized and excessive use of car rentals, id. $\S 1733$, and the third covering simple unauthorized use-“joyriding," $i d . \S 1736$.

204. Id. $\S 1735$.

205. 8 U.S.C. $\S 1326(1964)$.

206. PRoposed CODE $§ 1221$ (1)(d).

207. Id. § 1221(4). The approach of the Code, and its comparison with existing law is discussed in FINAL REPORT 99.

208. 8 U.S.C. $\S 1326$ (1964).

209. PROPOSED CODE $\S 1221(2)(b)$.

210. Id. $\S 3003$.

211. Id. § 1221(2)(b).

212. See notes 300-02 infra and accompanying text.

213. Proposed CODE $\S \S 1821-29$.

214. Pub. L. No.91-513.

215. FINAL REPORT 251.

216. Proposed CODE $\S 1824$. There was, however, a substantial objection to this .ecommendation. See Final RePORt 255.

217. FINAL REPORT 255. For a discussion of the reasons for the Code's provision, see $i d$. 
The scope of the offense of tax evasion under the proposed Code, which includes excise taxes on illicit liquor, is discussed in more detail below. ${ }^{218}$ The principal problem in the excise tax area, of course, is "moonshining," which is treated under present law by a number of felony provisions. ${ }^{219}$ The proposed Code carries these offenses forward in a simplified form, ${ }^{220}$ with the principal change made only to remove the possibility of felony treatment for the consumer. ${ }^{221}$ An attempt has also been made to square the presumptions of present law ${ }^{222}$ with the recent teaching of the Supreme Court in United States v. Gainey, ${ }^{223}$ involving the presumption from an unexplained presence at an unlawful still, ${ }^{224}$ and Turner $v$. United States, ${ }^{225}$ discussing presumptions arising from the possession of heroin and cocaine. ${ }^{226}$ These presumptions are treated in a single Code provision. ${ }^{227}$

While postal and interstate shipment theft, ${ }^{228}$ as well as postal and bank embezzlement ${ }^{229}$ are substantially changed, ${ }^{230}$ once the offenses of larceny and embezzlement are mastered, facility is achieved with respect to all theft and embezzlement provisions, as well as robbery of government property and car theft, since the Code standardizes the definitions of these crimes and only the applicable jurisdictional bases vary. ${ }^{231}$

218. See notes $272-78$ infra and accompanying text.

219. 26 U.S.C. $\S \S 5601-08$ (a) (1964); id. § 5608(b) (Supp. V, 1970).

220. PROPOSED CODE $\S \S 1401-09$.

221. Compare id. §1404 with 26 U.S.C. $\S \S 5601(a)(11), 5604(a)(1)$ (1964). See FinAL REPORT 148-49.

222. See, e.g., 21 U.S.C. $\S 174$ (1964) (possession of a narcotic drug is sufficient to authorize conviction); 26 U.S.C. $\$ 4704$ (a) (1964) (possession of narcotics without a tax stamp prima facie evidence of a violation); id. $\S 5601(\mathrm{~b})(1)$ (presence at the site of an unregistered still sufficient to authorize conviction).

223. 380 U.S. 63 (1965).

224. This presumption arises from 26 U.S.C. $\S 5601$ (b)(1) (1964).

225. 396 U.S. 398 (1970).

226. The presumption arose from 21 U.S.C. $\S \S 174,4704$ (a) (1964). The Court in Turner held that possession of heroin alone was sufficient to authorize conviction, since almost all heroin consumed in the United States is illegally imported. 396 U.S. at 408-16. With regard to cocaine, however, such a presumption was not proper since it is domesticelly available from legal sources. Id. at 418-19.

227. Proposed Code $§ 1405$. See Final Report $149-50$ for a discussion of this incorporation.

228. See 18 U.S.C. $\S 659$ (1964) (theft from interstate shipment); id. $\S 1341$ (fraud by use of the mails).

229. See, e.g.. id. § 643 (embezzlement).

230. These changes are discussed in Final Report 205.

231. Proposed CODE $\S 1740$. 
In addition to these statutes, which comprise the majority of federal prosecutions, it will be helpful to highlight several other noteworthy areas of the proposed Code, so that some idea of the range and substantive scope of the reforms proposed by the Commission may be observed.

General Purposes. For the first time in federal criminal jurisprudence, the proposed Code would explicitly recognize the inclusive and multi-purpose character of a modern penal code. ${ }^{232}$ Fundamentally, the Code rests on the notion of individual responsibility, and it recognizes the just need in any civilized society for the vindication of its more significant social norms by the imposition of merited punishment. ${ }^{233}$ At the same time, the Code eschews base revenge as a purpose, and recognition is given to the social need to seek the extrinsic purposes of measured deterrence, forward looking rehabilitation, and carefully circumscribed incapacitation. 234

Requirements of Culpability. Again for the first time, the various aspects of culpable states of mind will be defined, to avoid what $\mathrm{Mr}$. Justice Jackson called "the variety, disparity and confusion of [judicial] . . . definitions of the requisite but elusive mental element [in crime].",235 Definitions of "intentionally," "knowingly," "recklessly," "negligently," and "willfully" are all provided," which will have their chief function in distinguishing the various grades of offenses. Comparable schemes of culpability are found in the Model Penal Code ${ }^{237}$ and the New York Penal Law. ${ }^{238}$ They have, however, been criticized as introducing new language into the law which will serve only to confuse jurors and make the jury instruction process more difficult. ${ }^{239}$ Sharp controversy may thus be foreseen for these particular provisions. ${ }^{240}$

232. See generally J. Hall. General. Principles of Criminal. Law 296-324 (2d ed. 1960); Hart, The Aim of the Criminal Law. 23 LAW \& CONTEMP. ProB. 401 (1958).

233. PROPOSED CODE $\S 102(a)(i)$.

234. Id. § 102(ii). (iii), (iv). The purposes of the proposed Code are diseussed in Final. REPORT 2-3.

235. Morrissette v. United States, 342 U.S. 246, 252 (1952). There is at present no federal statutory provision setting out the circumstances under which proof of eulpability is required. FinAl. RePORT 29.

236. PROPOSED CODE $\S 302(1)$.

237. Model. Penal CODE $\S 2.02(2)$ (1962).

238. N.Y. PENAL. LaW $\S 15.05$ (McKinney 1967).

239. Kuh, $A$ Prosecutor Considers the Model Penal Code, 63 Colum. L. Rev. 608, 622-23 (1963). For a general discussion of the question, see Remington \& Helstad, The Mental Element in Crime-A Legislative Problem, 1952 WISC. L. Rev. 644.

240. FINAL RePORT 29. It has been reported that similar provisions led to the 
Mental Disease or Defect. The present federal law as to the insanity defense is in conflict. ${ }^{241}$ To provide for uniformity, the Code adopts a new nation-wide standard for exculpation based on mental

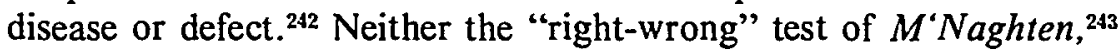
nor the "mental disease-product" test of Durham v. United States"24 was followed. Instead, the Commission recommended the "substantial capacity to appreciate and conform" test of the Model Penal Code, ${ }^{245}$ which has been followed in a number of circuit courts of appeal. ${ }^{246} \mathrm{~A}$ more far-reaching suggestion that would have integrated the mental disease or defect defense into the requirements of culpability was not adopted, although it was discussed. ${ }^{247}$

Limits on the Use of Force, Excessive Force, and Deadly Force. These provisions of the Code formulate rules which negatively define assault and homocide-that is, uses of force that are not assaults or homocides by virtue of law. Instead of casting them as standards, the application of which depends on all the facts and circumstances of the particular case, ${ }^{248}$ the proposed Code formulates them as precise rules of conduct. ${ }^{249}$ On the whole, the Code would confine the use of deadly force to when it is statutorily authorized, in the conduct of war, and as a last resort, defense of the individual or any other person. Contrary to present law, ${ }^{250}$ retreat from even the home or place of work would be required under circumstances that would involve only a minimal interference to the person menaced, ${ }^{251}$ including a person being defended by another. ${ }^{252}$

"reorganization" of the California codification project. Sherry, Criminal Law Revision in California, 4 J. LaW Reform 429 (1971).

241. The conflict is discussed in Final RePORT 40-42.

242. Proposed Code $\S 503$.

243. $10 \mathrm{Cl}$ \& F. 200, 8 [1843] Eng. Rep. 718.

244. 214 F.2d 862 (D.C. Cir. 1954).

245. Model Penal Code § 4.01(1) (1962).

246. Wade v. United States, 426 F.2d 164 (9th Cir. 1970); United States v. Smith, 404 F.2d 720 (6th Cir. 1968); United States v. Shapiro, 383 F.2d 680 (7th Cir. 1967); United States v. Freeman, 357 F.2d 606 (2d Cir. 1966).

247. Final Report 40-41.

248. See, e.g., Brown v. United States, 256 U.S. 335 (1921), which noted that failure to retreat is "a circumstance to be considered with all the others . . ." Id. at 343. For a discussion of the use of standards in the law, see 2 R. POUND, JuRISPRudence 127-32 (1959).

249. Proposed CODE $\S 607$.

250. Brown v. United States, 256 U.S. 335 (1921), where the Court noted that "[d]etached reflection cannot be demanded in the presence of an uplifted knife." 1 d. at 343. See also Beard $v$. United States, 158 U.S. 550 (1895).

251. Proposed CODE $\S 607$ (b).

252. Id. The use of force is discussed at more length in FINAL RePORT 50-51. 
Mistake of Law. Under current federal practice ignorance of the law is never an excuse. ${ }^{253}$ Likewise, federal law does not generally recognize a defense based upon a mistake of law. ${ }^{254}$ Where the definition of the offense itself requires knowledge of a legal duty, however, a mistake as to the character of the duty may be a defense. ${ }^{255}$ In contrast, the proposed Code provides that a good faith mistake of law made in reliance on a statute, opinion, or other official pronouncement would be an affirmative defense. ${ }^{256}$ Such a defense is recognized in the Model Penal Code ${ }^{257}$ and in several state codes. ${ }^{258}$ Because the requisite intent may not be readily susceptible of proof, ${ }^{250}$ a substantial body of opinion on the Commission preferred to limit the defense to situations wherc knowledge of the law would be relevant to culpability, ${ }^{260}$ a view that was based upon Holmes' belief that to allow the defense would be to encourage ignorance. ${ }^{261}$

Subsequent Prosecution by a Local Government: When Barred. Present federal law sometimes, ${ }^{262}$ but not always, ${ }^{263}$ bars federal prosecution subsequent to state action. In contrast, the proposed Code would extend that policy and formulate, under specified circumstances, an absolute statutory bar to subsequent state prosecution, where there has been a prior federal prosecution, ${ }^{264} \mathrm{a}$ result not now compelled under the relevant decisions of the Supreme Court. ${ }^{265}$ This provision was included over substantial objection, ${ }^{268}$ and its adoption will certainly generate controversy.

253. Blumenthal v. United States, 88 F.2d 522, 530 (8th Cir. 1937). See generally J. HALL, supra note 232, at 360-414 (1960); R. Perkins, Criminal Law 919-23 (1969).

254. Horning v. District of Columbia, 254 U.S. 135, 137 (1920).

25S. United States v. Murdock, 290 U.S. 389 (1933).

256. Proposed Code $\S 609$. See also Final Report 53.

257. Model Penal Code $\S 2.04$ (1962). The defense is recognized only if the ignorance or mistake negatives the material element of the offense. Id. $\S 2.04(\mathrm{a})$.

258. See, e.g., ILl. Rev. Code ch. 38, § 4-8 (Smith-Hurd 1964); N.Y. Penal Code $\$ 15.20$ (McKinney 1967).

259. It has been aptly observed of such defenses in the area of economic regulation, wherc it seems Proposed CODE $\S 609$ would have its greatest impact, that:

The required intent is so little susceptible of definite proof or disproof that the trier of fact is almost inevitably driven to asking, "Does he look like the kind who would stick by the rules or one who would cheat on them when he saw a chance?" This question, unfortunately, leads easily into another, "Does he look like my kind?" L. FuLLER, THE MORALITY OF THE LAW $72-73$ (1964).

260. FINAL REPORT 53.

261. O. Holmes, The Common law 41 (Howe ed. 1963).

262. See, e.g., 18 U.S.C. § 2117 (1964) (burglary of an interstate shipment).

263. See discussion of Abbate v. United Stales, infra note 265.

264. PROPOSED CODE $§ 708$.

265. In Bartkus v. 1llinois, 359 U.S. 121 (1959), the Court held that a state prosecution was 
Criminal Facilitation. The Code would introduce for the first time a new degree of criminal complicity. Although the cases are not without conflict, the general federal rule seems to require not only knowledge, but also a "stake in the venture" before a finding of criminal complicity can be made. ${ }^{267}$ Under the proposed Code, "facilitation" could be found where knowledge plus the substantial facilitation of an actual offense were present. ${ }^{268}$ This position was rejected for the Model Penal Code, ${ }^{269}$ but has been adopted in New York. ${ }^{230}$ The effect of this provision is essentially to create a lesser included offense to accomplice liability, since facilitation requires only knowledge, whereas an accomplice must have an actual intent. ${ }^{271}$

Tax Evasion. The respective formulations of the tax evasion provisions are essentially unchanged, as the proposed Code carries forward current statutory phraseology. The Code specifies the kinds of conduct now held to show an intent to evade, including, for example, concealing assets and failing to pay over taxes collected from another. ${ }^{272}$ After cataloguing these classic kinds of conduct from which the requisite intent for tax evasion may be inferred, the Code concludes with the general language of present law ${ }^{273}$ making it a crime to attempt "in any manner to evade or defeat . . . ." a tax. ${ }^{274}$ Evasion by filing a false tax return, however, is made an evasion offense even though there is no tax deficiency. ${ }^{275}$ False material statements, felonious under present law, ${ }^{276}$ will remain so under the proposed Code only where they are accompanied by an intent to

not barred by a prior acquittal in a federal action, and that such procedings 'caused no fourteenth amendment due process problems. Id. at 132-39. Similarly, in Abbate v: United States, 359 U.S. 187 (1959), the Court held that a federal prosecution was not barred because of an earlier state court conviction, and that this posed no double jeopardy problems under the fifth amendment. Id. at 193-95.

266. FINAL REPORT 64.

267. Compare United States v. Peoni, 100 F.2d 401,402 (2d Cir. 1938) (requiring a "stake") with Backun v. United States, 112 F.2d 635, 637 (4th Cir. 1940) (guilt requires no "stake").

268. PRoposed Code $\S 1002$.

269. Model Penal CODE $\S 2.06(3)$ (a) (1962).

270. N.Y. Penal Code $\S 115.00$ (McKinney 1967). See generally G. Willlams, Criminal. Law: The General Part 369-70 (2d ed. 1961).

271. FINAL REPORT 68-69.

272. Proposed CODE $§ 1401$.

273. 26 U.S.C. $\S 7201$ (1964).

274. PROPOSED CODE $\S 1401(1)(\mathfrak{f})$.

275. Id. $\S 1401(1)(\mathrm{a})$.

276. 26 U.S.C. $\S 7206$ (1964). 
evade, ${ }^{277}$ which would have to be shown by additional evidence. Finally, tax evasion is graded, as are theft provisions, depending on the amount of the deficiency. ${ }^{278}$

Para-Military Activities. For the first time in federal law, private armies would be outlawed. ${ }^{279}$ The acquisition, caching, use of, or training in, weapons for political purposes by associations of ten or more persons, other than those authorized by law, would be made a federal offense. ${ }^{280}$ Today, such organizations are merely required to register. ${ }^{281}$

Civil Rights and Elections. Proposals were placed before the Commission which would have substantially modified present law. ${ }^{282}$ The culpability element articulated in Screws $v$. United States ${ }^{283}$ - that there be shown a specific intent to deprive one of his federal rights, not simply an intent to beat or murder him-for example, would have been modified, and the requirement of "color of law" would have been omitted. ${ }^{284}$ The Commission recommended, however, the mere recodification of the present law without substantial modification, either to enlarge or restrict its scope, ${ }^{285}$ because it was felt that it would be unwise to go beyond the Civil Rights Act of $1968,{ }^{286}$ a matter so recently considered by the Congress.

Sodomy. Federal law presently deals with sodomy primarily through the operation of the Assimilated Crimes Act. ${ }^{287}$ Under the proposed Code, however, a new offense of aggravated involuntary sodomy, treated like forcible rape, would be recognized. ${ }^{288}$ Involuntary sodomy would also be subject to punishment, but consensual sodomy would not. ${ }^{2 x 9}$ The effect of this omission would be to make licit conduct now generally illicit under state law adopted and

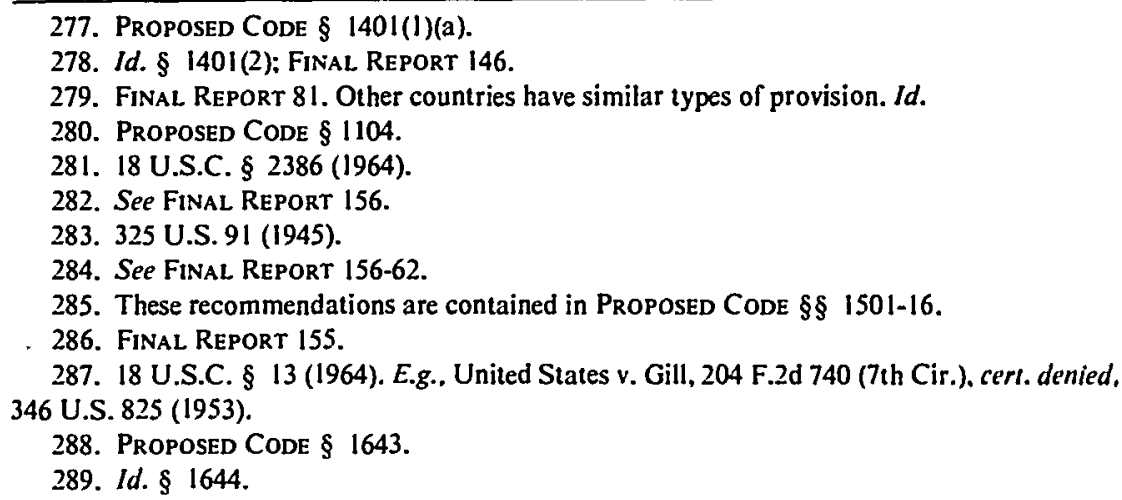


applicable in federal enclaves, a result which can be counted on to provoke sharp controversy. ${ }^{290}$

Riots. Based upon the recent District of Columbia statute, ${ }^{291}$ which has been held constitutional, ${ }^{292}$ the proposed Code's inciting to riot provisions will ensure a heretofore absent national uniformity. ${ }^{293}$ The Code eliminates the requirement of present law that the prosecution prove intent to incite to riot at the time that state lines are crossed. ${ }^{294}$ By virtue of the "piggyback" provisions of the Code, ${ }^{295}$ riot offenders may also be punished for any other crimes committed and, consequently, the punishment levels may be substantially raised where serious harm to persons or property is committed by either leaders or participants of riots. ${ }^{296}$ The "affecting commerce" jurisdictional reach of present law, however, is eliminated. Instead, federal jurisdiction is confined to cases where the Attorney General certifies that the riot involves, or apparently would involve, over a hundred persons and was substantially furthered from sources outside the state. ${ }^{297}$ The propriety of such certifications, however, are explicitly made not litigable. ${ }^{298}$ Finally, in any riot within the federal jurisdiction, it would be an infraction to disobey orders to clear the street, whether as a participant, bystander, or news media personnel. ${ }^{299}$

Firearms. Over considerable objection, the Commission recommended a federal ban on handguns, and a requirement of registration on a national scale for all firearms. ${ }^{300}$ Otherwise, the proposed Code contains only the implementing criminal provisions of an assumed regulatory law that would, of course, appear in other titles of the federal code..$^{301}$ Consequently, the Code sections, as presently drafted, are perfectly amenable to assimilating present la $w^{302}$ with or without substantial change.

290. The sodomy provisions are discussed in FINAL REPORT 188-90.

291. D.C. CODE \& 22-1122 (Supp. 1971).

292. United States v. Matthew, 419 F.2d 1177 (D.C. Cir. 1969).

293. FINAL REPORT 241-42.

294. Compare 18 U.S.C. $\$ 2101$ (a) (Supp. V, 1970) with Proposed CODE $\$ \S 1801-03$.

295. See notes $175-89$ supra and accompanying text.

296. See Final Report 242-43.

297. PRoposed CODE § $1801(4)$.

298. Id. at $\$ 104$.

299. Id. $\$$ 1804. See FINAL REPORT 245.

300. Proposed CODE $\S \S 1811-14$ (1ntroductory Note). See also Final RePort 246-47.

301. PROPOSED CODE $\S \S 1811-13$, and the comments thereto in FINAL RePORT 247-50.

302. Present law is basically constituted by the Gun Control Act of 1968, 18 U.S.C. 
Obscenity. Again over sharp objection, the Commission recommended an obscenity provision that constitutes a repudiation of the Commission on Obscenity and Pornography. ${ }^{303}$ The Code would retain as much of the presently constitutional obscenity law as possible. ${ }^{304}$ Felony provisions are continued for offensive dissemination, ${ }^{305}$ which will continue the pandering rule of Ginzberg $v$. United States, ${ }^{306}$ but will not, of course, disturb the possession allowance of Stanley $v$. Georgia. ${ }^{307}$ The Code also incorporates the Department of Justice's prosecutive policy with respect to private dissemination. ${ }^{308}$

Sentence of Death and Life Imprisonment. Although the Commission integrated into the proposed Code the abolitionists' position that capital punishment should be abolished, ${ }^{309}$ it did propose an alternative with respect to the procedural aspects of its implementation. ${ }^{310}$ The retentionist provisions, supported by a substantial portion of the Commission, entail preservation of capital punishment for selected crimes, including murder and treason, with jury and judicial guidelines codified for the imposition of the death penalty by enumerated aggravating and mitigating circumstances. ${ }^{311}$ The structure of the Code will accommodate either resolution of this issue. ${ }^{312}$

$\S \S 921-28$ (Supp. V, 1970); Title VII of the Omnibus Crime Control and Safe Strects Act of 1968, 18 U.S.C. App. $\S \S 1201-03$ (Supp. V, 1970); and the National Firearms Act Amendments of 1968, 26 U.S.C. $\S \S 5801-72$ (Supp. V. 1970).

303. Proposed Code § 1851. See Final Report 267-68.

304. The constitutional test for obscenity is contained in Roth v. United States, 354 U.S. 476 (1957).

305. Proposed Code § 1851(1).

306. 383 U.S. 463 (1966).

307. 394 U.S. 557 (1969).

308. See Redmond v. United States, 384 U.S. 264 (1966). Compare 18 U.S.C. $\$ \S 1461-65$ (1964) with Proposed CODE $\S 1851$. The position of the Commissioners who refused to read Stanley v. Georgia, 394 U.S. 557 (1969), as tolling the deathknell for obscenity regulation was vindicated in United States v. Reidel, 402 U.S. 351 (1971) and United States v. Thirty-seven Photographs, 402 U.S. 363 (1971).

309. Proposed CODE $\S 3601$.

310. Proposed Code (Provisional) § 3601. The Supreme Court's decisions in McGautha v. California, 402 U.S. 183 (1971), and Crampton v. Ohio, 402 U.S. 183 (1971), now make most of the issues surrounding the implementation of the death penalty policy questions to be resolved by the legislature. In this connection, the Subcommittee on Criminal Laws and Procedures is conducting a state survey of law and practice in those states which have adopted the two-stage procedure. It is expected that the results of this survey will be embodied in hearings to be held by the Subcommittee in the Fall of 1971.

311. Proposed Code (Provisional) \& 3604.

312. See FinAl REPORT 310-11. which also includes the arguments for and against the abolition of capital punishment. 


\section{CONCLUSION}

The proposed Code may, in one sense, be seen as a model of what an attempt at re-codification may accomplish when the theoretical framework of the Code is consciously worked out as an initial matter and the substantive provisions are then carefully integrated into that framework. The principle benefit of such a procedure is that it provides the process of codification with a flexible yet integral tool. Hence, once the theoretical keystone of the proposed Code was formulated - the new treatment of federal jurisdiction-its other essential architectural features naturally flowed. The flexibility of the framework of the proposed Code also means that its various specific provisions are wholly adjustable to reflect legal and policy judgments entirely different from those tentatively posed by the Commission. In short, because the structure of the Code was arranged so that each provision could be treated as a separate policy issue, the Code can, without undue effort, be adapted to fit a variety of substantive positions. It is to be hoped that this feature of the Code will materially contribute to its ultimate successful processing. No one objectionable aspect of the Code should lead to its entire rejection.

Analysis of the structural aspects and substantive provisions of the proposed Code is, of course, important. Nevertheless, attention must also be given to the historical context in which the proposed Code was drafted. This attempt at codification, like those before it and those that will follow it, ought not be examined or carried out in a vacuum. Any attempt at codification must be recognized to be a part of a continuing historical process - a part of the overall evolution of the law-and it ought to be undertaken with due regard for the clear teaching of history. In the consideration of the proposed Code, therefore, there are lessons which the Congress and the nation should draw from the history of the codification movement, and which should be applied to the consideration of the issues posed by the Code.

Initially, history teaches that no one man, or even a few men working together can effectively sum up or reform the law of their own time and place ${ }^{313}$ - the whole of the law is a field simply too vast

\footnotetext{
313. Justice Cardozo made this point when he wrote:

For the task in truth is one to baffle the wisdom of the wisest. Law is the expression of a principle of order to which men must conform in their conduct and relations as members of society, if friction and waste are to be avoided among the units of the aggregate, the atoms of the mass. The expression may be false if those who formulate it, lawyer and judge and legislator, are blind to any phase of the life whose inner harmony
} 
to be tilled alone. Justinian's Code, embodying Tribonian's work, shows the limits of the imagination and scholarship of Tribonian and his associates. ${ }^{314}$ Similarly, the codes of Field and Livingston, great though they were, carry with them the inevitable defects of limited authorship. ${ }^{315}$ What this should teach those of us involved in the process of codification, reform, and revision, of course, is that it is necessary to bring to bear on the issues raised by the recommendations of the National Commission the critical judgment of as many individuals as possible, not just those from the academy, but investigators, trial lawyers, judges, and members of the community at large -we must, in short, follow the path of Germany in the development of its monumental civil code. ${ }^{316} \mathrm{Had}$ Livingston, for example, taken the trouble to involve the practicing bar of Louisiana in his project, his code might have been found acceptable. Able and experienced though the Commission, its staff, its consultants, and its advisory committee may have been, its greatest wisdom lay in recognizing this historical lesson and offering its work product as simply a basis upon which Congress could work the nation's will. Consequently, the careful course Congress followed in the revision of 1948 recommends itself again, especially since codification and reform have been added to the basic task of revision. Only by involving all segments and viewpoints of the community in the process of recodification will it be possible to say, at the successful end of the task, that the Congress' work product expresses well the judgment of the nation on what a citizen may and may not do without incurring the community's formal condemnation.

History also teaches the futility of haste. The codes of Justinian and Napolean carried with them the imperfections of too little attention to detail. Each stands in sharp and unfavorable contrast with the remarkable effort of the German nation in the production,

\footnotetext{
they are commissioned to interpret and maintain. No one of us has a vision at once so keen and so broad as to penetrate these unsounded depths and gather in its sweep this enveloping horizon. We can only cling for the most part to the accumulated experience of the past, and to the maxims and principles and rules and standards in which that experience is embodied. Little is the positive contribution that any one of us can hope to make, the impetus that any one of us can give, to the movement forward through the ages. That little will call for the straining of every faculty, the bending of every energy, the appeal to every available resource, within us or without. B. CARDOzO, THE GROWTH OF THE LAW $140-41$ (1924).

314. See notes 9-11 supra and accompanying text.

315. See notes 23-26 supra and accompanying text.

316. See notes $18-19$ supra.
} 
criticism, and recodification of its civil code. ${ }^{317}$ It is not, of course, necessary that an ideal or perfect product be produced; the study of history inculcates in its careful students a measure of humility. The code that the Congress writes today will serve others tomorrow, but we must recognize that today's work will be tomorrow reexamined ${ }^{318}$ - if nothing else, history teaches that each new generation rightly desires to develop its own fundamental code of conduct. ${ }^{319}$ Enough time must be spent to produce a workable and just code for today, without laboring too long in an idle attempt to secure perpetual validity through perfection.

We must remember, moreover, that history tells us that a code must be written for its own time and place, taking into account the needs and opinions of the people it will govern as they are, then and there. Livingston's code, too far ahead of its time, greatly influenced the future, but it never governed a present. ${ }^{320}$ We are indeed "one people," in Mr. Justice McKenna's words, ${ }^{321}$ but much of our strength as a nation stems from our diversity. Charles V showed great wisdom in recognizing that deference to diversity was a price worth paying to achieve the genuine humanitarian advances of the Carolina. Justice Holmes summed up this teaching of history when he observed that "[t]he first requirement of a sound body of law is that it should correspond with the actual feelings and demands of the community, whether right or wrong." 322 The new Code will scarcely be considered worthwhile if its enactment requires any place or region unnecessarily to conform to national standards not their own. Recall, too, that experience with the Carolina shows that a humanitarian rule in one

317. Id.

318. See 3 Maitland, supra note 7, at 439.

319. In this regard Justice Cardozo once observed:

The flaws . . . there [are] . . . in every human institution. Because they are not only there but visible, we have faith that they will be corrected. There is no assurance that the rule of the majority will be the expression of perfect reason when embodied in constitution or in statute . . . The tide rises and falls, but the sands of error crumble.

....

... I sometimes think that we worry ourselves overmuch about the enduring consequences of our errors. They may work a little confusion for a time. In the end, they will be modified or corrected or their teachings ignored. The future takes care of such things. In the endless process of testing and retesting, there is a constant rejection of the dross, and a constant retention of whatever is pure and sound and fine. B. CARDozo, ThE Nature of the Judicial Process 177, 179 (1921).

320. See notes 22-23 supra and accompanying text.

321. Hoke \& Economides v. United States, 227 U.S. 308, 322 (1913).

322. O. Holses, supra note 261 , at 36. 
region may be baneful in another. ${ }^{323}$ To be sure we cannot remain a single nation unless we give due regard, in all places and in all regions, to the fundamental human rights possessed by all our citizens. But standards of personal conduct do vary from region to region. Due attention, therefore, must be given in the process of codification to the legitimate demands of our nation's diversity. ${ }^{324}$

There is no surer lesson of history than that politics should not be mixed in the process of codification, reform, and revision, although it will inevitably, in some measure, taint the work of any such endeavors. Bacon's plan for the reform of the common law aborted because of politics. ${ }^{325}$ Napolean's Code became possible only through extraordinary legislative means. ${ }^{326}$ Similarly, the work of Livingston in Louisiana and Field in New York had to run the gauntlet of political criticism. ${ }^{327}$ The issues of crime and criminal justice, however, are far too important to be made the subject of narrow political advantage. Too much is at stake and too great is the need for reform to run the risk of losing it all for the momentary gains of politics. Debate, on the other hand, is not only to be expected, but to be welcomed, for it is only through the examination of diverse views stated by able advocates that we may reach sound decisions. No one has a monopoly on truth, and anyone who has an open mind can learn from those who disagree with him. In evaluating the proposed Code, therefore, Congress and the nation must attempt to put politics aside, or at least minimize its impact, and pledge themselves to a common goal-a comprehensive new Code. Differences should be confined to particular issues and not generalized to the Code itself. Otherwise, the attempt will be in vain.

323. See note 69 supra and accompanying text.

324. Justice Black in Younger v. Harris, 40 I U.S. 37 (1971) put it this way:

$[0]$ ne familiar with the profound debates that ushered our Federal Constitution into existence is bound to respect those who remain loyal to the ideals and dreams of "Our Federalism." The concept does not mean blind deference to "States' Rights" any more than it means centralization of control over every important issue in our National Government and its courts. The Framers rejected both these courses. What the concept does represent is a system in which there is sensitivity to the legitimate interests of both State and National Governments, and in which the National Government, anxious though it may be to vindicate and protect federal rights and federal interests, always endeavors to do so in ways that will not unduly interfere with the legitimate activities of the States. 1t should never be forgotten that this slogan, "Our Federalism," born in the early struggling days of our Union of States, occupies a highly important place in Nation's history and its future. Id. at 44-45.

325. See notes 20-21 supra and accompanying text.

326. See note 17 supra and accompanying text.

327. See notes $22-25$ supra and accompanying text. 
1 would be less than frank, moreover, if I did not express my concern that the recent history of legislation in the criminal justice area in the Congress has raised the serious question of whether the benefits achieved have not been purchased at too high a price of social division. ${ }^{328}$ Regardless of how one views the penal law, its importance to society cannot be questioned. It is what men rely upon for protection against injury, and it is what official agencies use to justify the employment of official force. Its promise of safety is, therefore, matched only by its power to destroy. Professor Herbert Wechsler. aptly put it this way:

If penal law is weak or ineffective, basic human interests are in jeopardy. If it is harsh or arbitrary in its impact, it works a gross injustice on those caught within its toils. The law that carries such responsibilities should surely be as rational and just as law can be. Nowhere in the entire legal field is more at stake for the community or for the individual. ${ }^{329}$

In processing the proposed Code, therefore, I would hope that every man of good faith will recognize in others a similar dedication to the welfare of society and the freedom of the individual. No man of good faith seeks either to establish a police state or to make it easier for the criminal to achieve immunity from the consequences of his conduct - and rational consideration of the proposed Code will not be advanced by too lightly suggesting the presence of such desires.

Finally, I would hope that the experience of this national effort at codification, if properly carried out, might serve as a guide for the expanding movement of recodification presently taking place among the state legislatures. ${ }^{330}$ The recommendations of the National Commission offer to the Congress an unparalleled opportunity not only to enact a comprehensive new federal criminal code, but also to influence the course of the development of criminal jurisprudence throughout the nation. I call, therefore, for the exercise of quiet reason and wise leadership, not emotional rhetoric as the Congress and the nation now move to the challenge of a new, modern federal criminal code.

328. See, e.g., the criticisms leveled at the Organized Crime Control Act of 1970, Pub. Law No. $91-452$, which are considered in McCleilan, supra note 88.

329. Wechsler, The Challenge of a Model Penal Code, 65 HARv. L. Rev. 1098 (1952).

330. The status of substantive penal law revision is indicated in an appendix to this article. See pp. 714-16 infra. 


\section{APPENDIX}

\section{Status of State Substantive Penal Law Revision*}

1. REVISED CODES \& THEIR EFFECTIVE DATES: (11)

Colo. Rev. Stat. AnǸ. ch. 40, $\S 40-1-$ I to 40-25-5 (1963) (eff. July 1, 1972).

Conn. Gen. Stat. Ann., Penal Code tit. 53, §§ 53A-1 to 53A-215 (1969) (eff. October I, 1971).

GA. CoDE AnN. tit. 26, $\S 26-101$ to 26-9925a (1970) (eff. July 1, 1969).

IDAho Code ANN. tit. I8, §§ [8-10 I to 18-7303 (Supp. 1969) (eff. January I, 1972).

ILL. Rev. Stat. ch. 38, §§ 1-3 to 42-2 (1969) (eff. January 1, 1962).

Kan. Stat. ANN. ch. 2, $\S \S 21-3101$ to 2 l-46l5 (Supp. 1969) (eff. July 1, 1970).

La. Rev. Stat. AnN. tit. $14, \S \S 14: 1$ to $14:$ [42 (1951) (eff. July 29, 1942).

Minn. Stat. Ann. ch. $609, \S \S 609.01$ to 609.655 (1964) (eff. September 1, 1963).

N.M. Stat. AnN. ch. 40A, $\S \S 40 A-l-1$ to $40 A-29-23$ (1964) (eff. July I, 1963).

N.Y. Penal Law ch. $40, \S \S 1.00$ to 500.10 (McKinney 1967) (eff. September [, 1967).

WIS. Stat. ANN. tit. $45, \S \S 939.01$ to 947.15 (1958) (eff. July 1, 1956).

II. CURRENT SUBSTANTIVE PENAL CODE REVISION PROJECTS:

A. REVISIONS COMPLETED. BUT NOT YET ENACTED: ([4)

Alaska (Sen. Bill No. 5; 197 I Legislature).

Delaware (1967) (dormant for 2 yrs.; will probably be reintroduced in next Legislature).

* As of May, 1971, from Testimony of Professor Herbert Wechsler before the Subcomm. on Criminal Law and Procedures of the Senate Comm. on the Judiciary, to be published as Hearings, pt. 2, which is cited to in full at note 5 above. 
Hawaii (being reviewed by Legislature).

Maryland (proposed new Code with Commentary to be available for distribution last summer).

Michigan (1967) (Introduced in 1971 Legislature: House Bill No. 4004; Sen. Bill No. 2. In House Judiciary).

Montana (Proposed Montana Criminal Code of 1970) (Criminal Law Comm'n to reconsider and revise some sections; plan to submit Code to 1973 Legislature).

New Hampshire (1969) (submitted to 1971 Legislature).

Oregon (passed Senate; Hearings in House Judiciary end of April).

Pennsylvania (Pennsylvania Proposed New Crimes Code-including separately proposed code of sentencing procedure [January 197I] submitted to 1971 Legislature. Presently, in Senate Judiciary Committee [Sen. Bill 440]).

Puerto Rico (1967).

Texas (Introduced February 4, 1971 in Legislature: Sen. Bill 250 \& House Bill 419).

United States (Proposed New Federal Criminal Code submitted to Congress January 1971. Senate Judiciary Subcommittee on Criminal Laws and Procedures to hold Hearings).

Vermont (tentative enactment 1970, being reviewed by two standing Judiciary Committees).

Washington (Proposed Criminal Code [Dec. 1970] in Senate Judiciary Committee).

B. REVISIONS WELL UNDER WAY: (7)

California (since 1963).

Iowa (plan to submit Code to 1972 Legislature).

Kentucky (plan to submit Code [to be printed fall 1971] to January 1972 Assembly).

Massachusetts (plan to submit Code to 1972 Legislature).

New Jersey (plan to submit Final Draft July 15, 1971 to Governor and Legislature).

Ohio (hope to have bill ready shortly).

Rhode Island (Governor's Task Force since 1968). 
C. REVISIONS AT VARYING PRELIMINAR Y STAGES: (6) Alabama, Florida, Missouri, Nebraska, North Carolina, South Carolina

D. REVISIONS AUTHORIZED-WORK NOT YET BEGUN: (4)

Arizona, Oklahoma, North Dakota, Virginia

E. CONTEMPLATING REVISIONS: (3)

Arkansas, Maine, Utah

III. NO OVER-ALL REVISIONS PLANNED: (7)

Indiana, Mississippi, Nevada (recodification with minor changes enacted 1967), South Dakota, Tennessee, West Virginia, Wyoming. 